\title{
Upper Campanian ammonites from the Ozan- Annona Formation boundary in Southwestern Arkansas
}

\author{
W. J. KENNEDY AND W. A. COBBAN
}

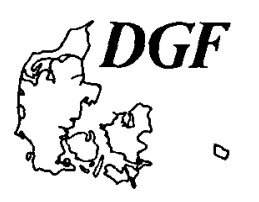

\begin{abstract}
Kennedy, W. J. and Cobban, W. A.: Upper Campanian ammonites from the Ozan-Annona Formation boundary in Southwestern Arkansas. Bull. geol. Soc. Denmark, Vol. 40 pp. 115-148, Copenhagen, June 3th, 1993. https://doi.org/10.37570/bgsd-1993-40-04

The top of the Ozan Formation and basal phosphate nodule bed of the Annona Chalk near Okay in Howard County, Arkansas yield rich upper Campanian ammonite faunas. The Ozan assemblage is: Nostoceras (Nostoceras) archiacianum (d'Orbigny, 1842), Didymoceras donezianum (Mikhailov, 1951), D. sp., and Neancyloceras cf. bipunctatum (Schlüter, 1872), and is of wholly northwest European aspect, correlating with the upper part of the classic upper Campanian Nostoceras (Bostrychoceras) polyplocum zone, the D. donezianum zone of Blaszkiewicz (1980) and the lower part of the Belemnitellalangei zone of the European White Chalk sequence. The basal Annona phosphates include cosmopolitan taxa such as Pseudophyllites, Desmophyllites, Pachydiscus and Menuites, plus 11 heteromorph species of Gulf Coast and U.S. Western Interior type that can be correlated with the Campanian Baculites gregoryensis and $B$. reduncus zones of the Western Interior sequence. Two new species of Nostoceras (Nostoceras) are described from the base of the Annona.
\end{abstract}

William A. Cobban, U.S. Geological Survey, Paleontology and Stratigraphy Branch, Box 25046, Mail Stop 919, Federal Cenier, Denver, Colorado 80225, U.S.A. W. James Kennedy, Geological Collections, University Museum, Parks Road, Oxford OXI 3PW, U.K. October 26th, 1990.

The problem of interregional correlation of Upper Cretaceous marine sequences was one that Tove Birkelund devoted much time and effort to, and one which we discussed with her on many occasions, in Denmark, Oxford and Denver. The present contribution is dedicated to her memory, and deals with the correlation of the Campanian stage, on the basis of faunas from the southeastern United States, where elements of U.S. Western Interior and north-west European affinities co-occur in a limited stratigraphic interval.

\section{Introduction}

The Ozan and Annona Formations are the lower two formations of the Upper Cretaceous Taylor Group in southwestern Arkansas and northeastern Texas (text-figs. 1, 2). The term Ozan Formation was introduced (according to Dane 1929, p. 58 ) in an otherwise anonymous United States Department of Interior Memorandum for the Press (no 8823), dated September 10, 1926. Dane (1929, p. 58) subsequently described the Ozan at its type locality as "sandy, micaceous marl, and in its lower part, of glauconitic marl and sand", and recorded an extensive list of megafossils, including Baculites asper Morton. Pessagno (1969) studied planktonic foraminifera samples from the base of the formation in Texas and from a few metres below the top at White Cliffs, Arkansas (text-fig. 2). He assigned the formation to his lower Pseudotextularia elegans zonule of his Globotruncana elevata subzone of the Globotruncana fornicata-G. stuartiformis assemblage zone.

The Annona Chalk was initially described by Hill (1888), who called it the White Cliffs Chalk, from exposures along the White Cliffs on the Little River in southwestern Arkansas. The name was preoccupied, however, and Hill (1901) renamed the unit the "Anona chalk" (a misspelling corrected by Veatch (1906)) from outcrops northwest of Annona in Red River County, Texas. The unit is as much as $90 \mathrm{~m}$ thick in Texas, but thins markedly in southwestern Arkansas, from $27 \mathrm{~m}$ in Litte River county to $10.4 \mathrm{~m}$ at the Okay quarry at Okay, Howard County, and to only 36 $\mathrm{cm}$ between Columbus and Yancy in Hempstead County (Bottjer, 1978, 1981, 1985, 1986). The Annona wedges out to the northeast, and the 


\begin{tabular}{|c|c|c|}
\hline GROUP & FORMATION & LITHOLOGY \\
\hline \multirow{3}{*}{ TAYLOR } & $\begin{array}{l}\text { MARLBROOK } \\
\text { MARL }\end{array}$ & $\begin{array}{l}\text { Soft, grey, chalky marl } \\
50 \mathrm{~m}\end{array}$ \\
\hline & $\begin{array}{c}\text { ANNONA } \\
\text { CHALK }\end{array}$ & Massive white chalk $1-30 \mathrm{~m}$ \\
\hline & $\begin{array}{c}\text { OZAN } \\
\text { FORMATION }\end{array}$ & $\begin{array}{c}\text { Calcareous, sandy clay } \\
\text { with glauconite sand } \\
70 \mathrm{~m}\end{array}$ \\
\hline
\end{tabular}

Text-fig. 1. Lithostratigraphic divisions of the Taylor Group in Arkansas. Modified after Bottjer (1981).

succeeding Marlbrook Marl rests unconformably on the Ozan (text-fig. 3).

The facies is rhythmically bedded alternations of bioturbated more-or-less argillaceous chalks, described in detail by Bottjer (see above), who has made bed-by-bed correlations across the area. Individual rhythms can be correlated, aided by the presence of a marker bentonite high in the sequence. These show that thinning is a reflection of an increasing stratigraphic break at the base of the Annona, marked by a striking basal phosphate bed that is the source of the bulk of the ammonites described here.

Pessagno (1969) placed the lower part of the Annona in the Globotruncana calcarata zonule of his Globotruncana elevata subzone of the Globotruncana fornicata-G. stuartiformis assemblage zone of the upper Campanian, but did not study samples form the top of the unit.

No published ammonite dating of the Ozan and Annona Formations is known to us.
Locality details

Ammonites described here all come from the Okay quarry of the Ideal Cement Company in the NW1/4SW1/4 sec. 30 , T. 11 S., R. 27 W., in Howard County, Arkansas (text-fig. 2). A section, modified after Bottjer $(1978,1981,1985)$ is shown in text-fig. 3. Inasmuch as the Annona Chalk is stripped away from the underlying Ozan, the top metre or so of the Ozan is greyweathering chalky marl, that is exposed on the quarry floor, and yields distorted composite moulds of ammonites as well as originally calcitic fossils with mineralogy unaltered. The contact with the overlying Annona is a sharp discontinuity surface, with chalk-filled Thalassionides burrows piped down into the Ozan (Bottjer, 1985, fig. 6.2). The outcrop is strewn with phosphatic nodules and moulds of fossils derived from the basal part of the Annona, and sometimes welded

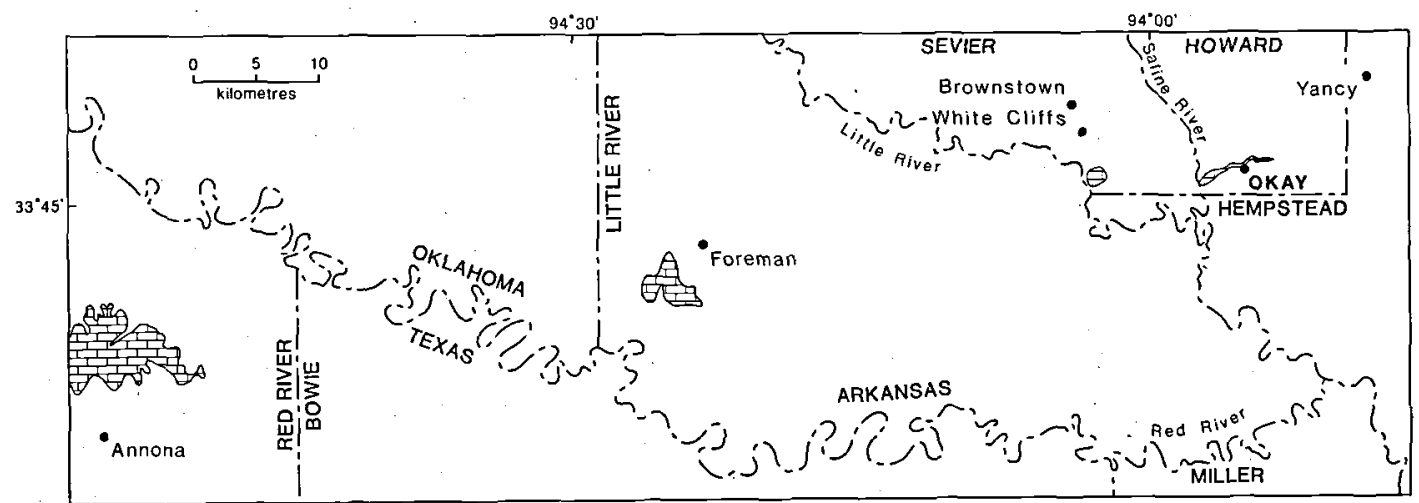

Text-fig. 2. The outcrop of the Annona Chalk in southwestern Arkansas, showing localities mentioned in the text. 


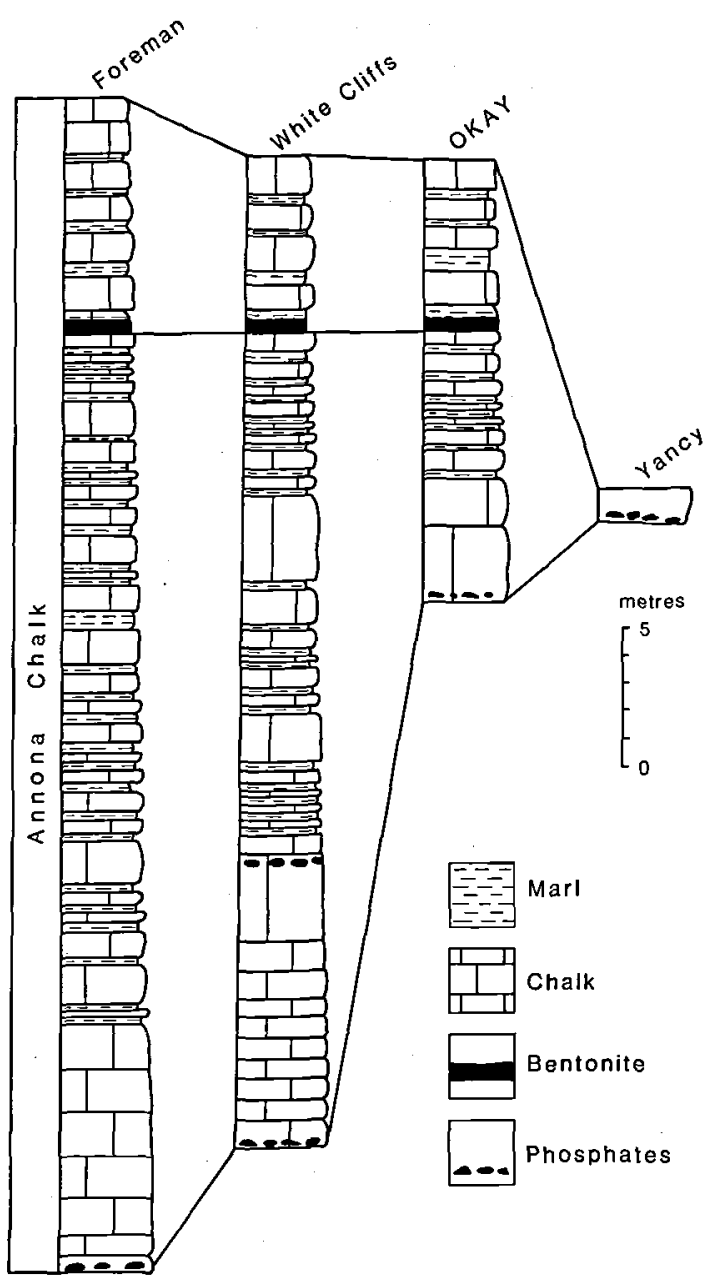

Test-fig. 3. Lithostratigraphy of the Annona Chalk at selected Iocalities in southwestern Arkansas. Modified after Bottjer (1981).

into a phosphatic conglomerate. The phosphates are black, pale brown and cream coloured. Ammonites, notably Baculites are abundant, sometimes with irridescent surfaces, occurring as moulds of camerae and body chamber. The show features typical of other Gulf Coast phosphate beds as described by Fürsich, Kennedy and Palmer (1981) and are bored, worn and encrusted by phosphatised and unphosphatised epizoans. Apart from the ammonites, there are common Eutrephoceras, Inoceramus, Pycnodonte, Spondylus, Atreta, avellanid, trochid and pleurotomariid gastropods, solitary corals, poriferans and elasmobranch debris. Age of the faunas.

The unphosphatised fauna from the top of the Ozan Formation is: Nostoceras (Nostoceras) ar- chiacianum (d'Orbigny, 1842), Didymoceras donezianum (Mikhailow, 1951), Didymoceras sp., and Neancyloceras cf. bipunctatum (Schlüter, 1872). None of these species has been previously recorded from North America. Rather, the assemblage is a typically north-west European one, indicative of the upper upper Campanian Bostrychoceras polyplocum zone of the classic fourfold zonation of the Campanian (Kennedy, 1986). Two of the species occur in the Campanian type region of northern Aquitaine in France, where $N$. cf. bipunctatum occurs in Assise $\mathrm{P}^{3}$ and $N$. (N.) archiacianum in Assise Q (Kennedy, 1986, table 2).

A more precise ammonite zonation of the upper Campanian has been recognised in the Vistula Valley, Poland, where Blaszkiewicz (1980) established the following succesion:

\section{Nostoceras pozaryskii zone (youngest) \\ Upper Didymoceras donezianum zone \\ Campanian Bostrychoceras polyplocum zone Neancyloceras phaleratum zone (oldest)}

Didymoceras donezianum and $N$. bipunctatum both characterise the $D$. donezianum zone and provide a precise dating for the top of the Ozan in north-west European terms. The donezianum ammonite zone is equivalent to the lower part of the range of the belemnite Belemnitella langei, index of the uppermost upper Campanian zone of the North German White Chalk sequence (Ernst and Schmid, 1979; Christensen, 1975).

The fauna from the basal Annona phosphate bed is: Pseudophyllites sp., Desmophyllites diphylloides (Forbes, 1846), Pachydiscus (Pachydiscus) sp., Menuites cf. portlocki (Sharpe, 1855), Placenticeras sp., Nostoceras (Nostoceras) arkansanum sp. nov., $N$. (N.) platycostatum sp. nov., Didymoceras tortum (Meek and Hayden, 1858) (relatively common), D. cochleatum (Meek and Hayden, 1858), D. mortoni (Hall and Meek, 1856; abundant), Didymoceras sp., Oxybeloceras crassum (Whitfield, 1877) (common), Baculites taylorensis Adkins, 1929 (abundant), Baculites reduncus Cobban, 1977 (rare), Baculites sp., (abundant) and Trachyscaphites redbirdensis Cobban and Scott, 1964 (scare). This is still an upper Campanian assemblage in a north-west 


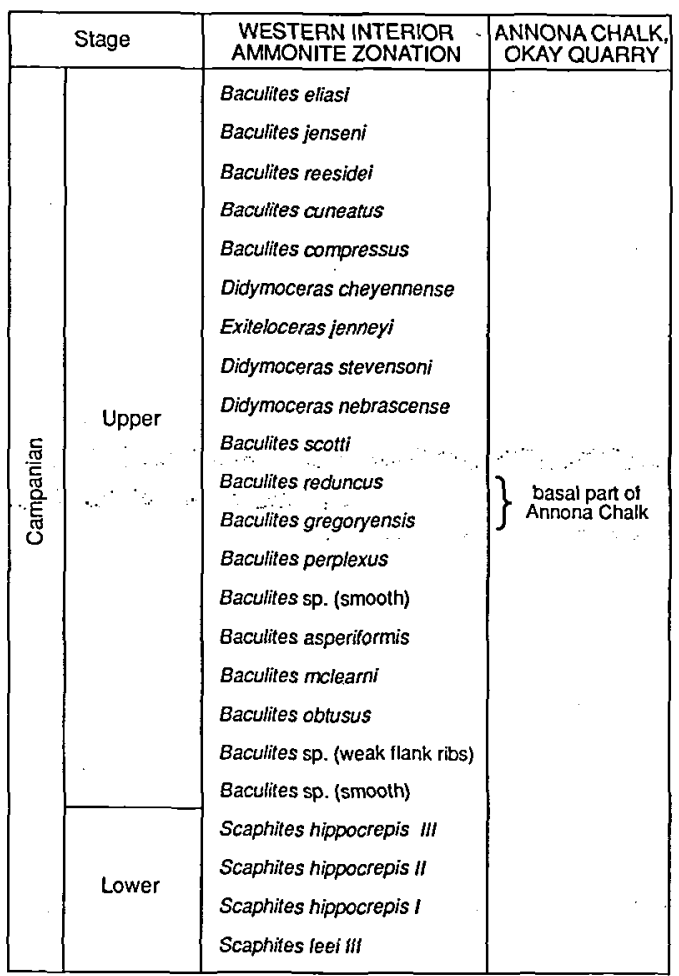

Text-fig. 4. Campanian ammonite zonation for the Western Interior of the United States, showing the probable age assignment of the basal Annona fauna at Okay, Arkansas.

European sense. But whereas the top Ozan fauna was exclusively north-west European in composition, the basal Annon fauna is of mixed affinities. Pseudophyllites and Desmophyllites are, by the late Campanian, relatively cosmopolitan and long-ranging taxa. Baculites taylorensis is a Gulf Coast species, and $N$. (Nostoceras) arkansanum sp. nov. and $N$. (N.) platycostatum sp. nov. are ancestors of well-known Gulf Coast species. The Placenticeras, Baculites reduncus and Trachyscaphites redbirdensis were previously known from both Gulf Coast and Western Interior, but six of the remaining species, including those that are numerically dominant, are of Western Interior type. The presence of Menuites cf. portlocki suggest no more than upper Campanian in a northwest European sense, and no more precise transAtlantic correlation is possible. Correlation with the Western Interior sequence is clear from discussions in the text: the bulk of the Interior elements in the basal Annona phosphate bed are markers for the Baculites gregoryensis and $B$. reduncus zones (text-fig. 4).
Conventions

Suture termiology: The system of Wedekind (1916) as reviewed by Kullmann and Wiedmann (1970) is used here. $\mathrm{E}=$ external lobe, $\mathrm{L}=$ lateral lobe, $\mathrm{U}=$ umbilical lobe, $\mathrm{I}=$ internal lobe.

Dimensions: All dimensions are given in milimetres: $\mathrm{D}=$ diameter, $\mathrm{Wb}=$ whorl breadth, $\mathrm{Wh}$ = whorl height, and $U=$ umbilicus; $c=$ costal and ic $=$ intercostal. Figures in parentheses refer to dimensions as a percentage of diameter. The term rib index as applied to heteromorphs is the number of ribs in a distance equal to the whorl height at the midpoint of the interval counted.

Synonymies: Only citations which include illustrations of material or important systematic, stratigraphic or geographic information are included.

Repositories of specimens: The following abbreviations are used to indicate the repositories of specimens:

BGS: British Geological Survey, Keyworth, Nottinghamsire.

BMNH: Natural History Museum, London

USNM: U.S. National Museum of Natural History, Washington D.C.

\section{Systematic Palaeontology}

Order AMMONOIDEA Zittel, 1884, pp. 355, 392

Suborder LYTOCERATINA Hyatt, 1889, p. 7 Superfamily TETRAGONITACEAE Hyatt, 1900 , p. 568

Family TETRAGONITIDAE Hyatt, 1900, p. 568

Genus Pseudophyllites Kossmat, 1895, p. 137 (41)

Type species: Ammonites indra Forbes, 1846, p. 105 , pl. 11 fig. 7 , by original designation.

Pseudophyllites sp.

Text-fig. 8E, F

Discussion: USNM 41257 is a $50 \mathrm{~mm}$ long phos- 


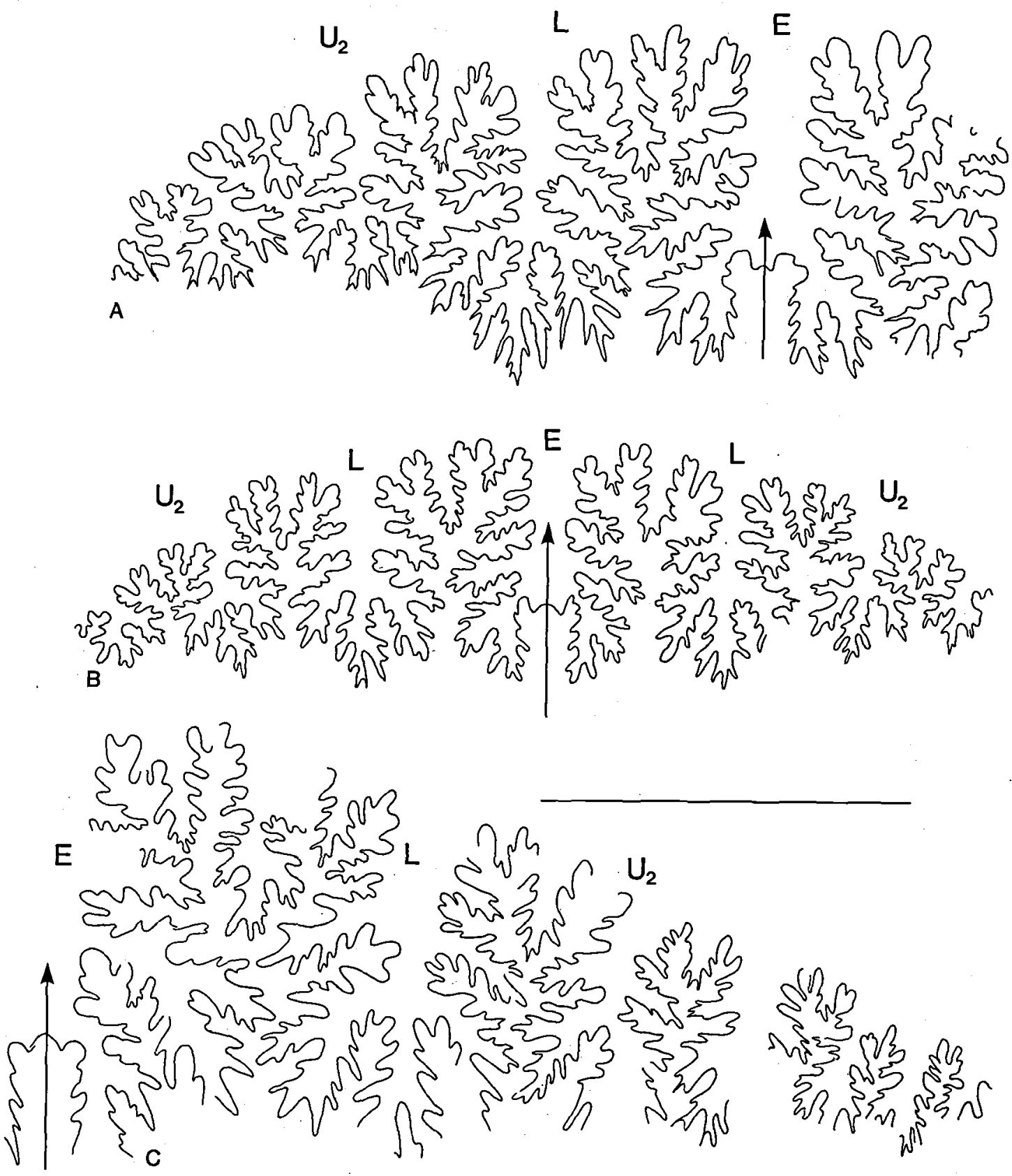

Text-fig. 5. External sutures. A, B, Menuites cf. portlocki (Sharpe, 1855), USNM 411265 and 411264; C, Desmophyllites diphylloides (Forbes, 1846), USNM 411259 . Bar scale is $10 \mathrm{~mm}$.

phatised fragment with a complex lytoceratid suture that shows part of a massive septal lobe, indicating the presence of Pseudophyllites in the fauna. The genus is rare in North America, but also occurs in the upper Campanian of Mississippi and New Jersey. The present fragment has a lanceolate external saddle and is likely to be $P$. indra (Forbes, 1846) (p. 105, pl. 11, fig. 7; see Kennedy and Klinger, 1977 , p. 182, figs. 19a-f, 20-22; Henderson and McNamara, 1985, p. 50, pl. 2, figs. 7, 8; pl. 3, figs. 4 , 5; text-fig. 5a, d). 

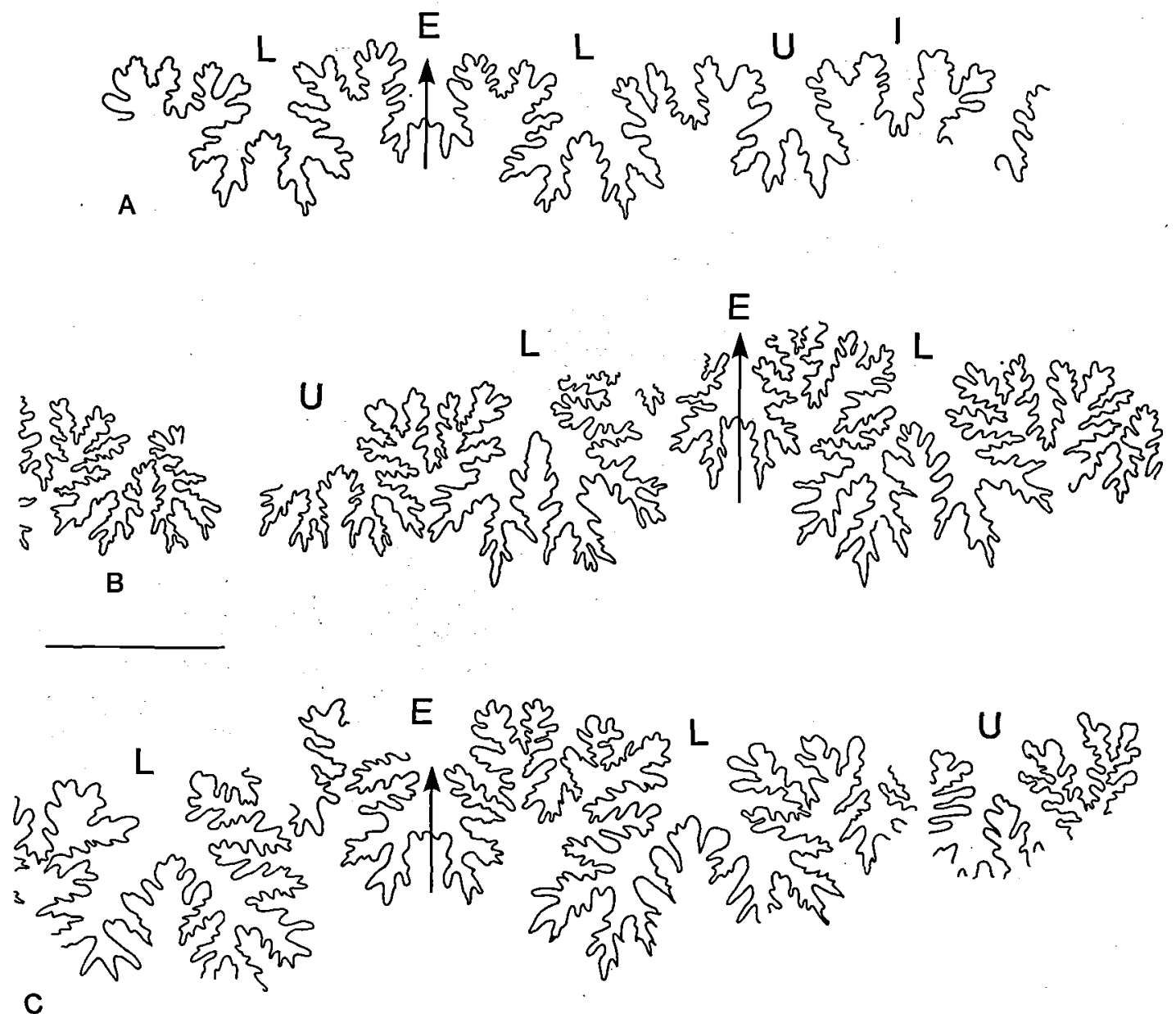

Text-fig. 6. Sutures. A, Didymoceras sp. USNM 411361. B, Didymoceras tortum (Meek and Hayden, 1858), USNM 411357. C, Didymoceras cochleatum (Meek and Hayden, 1858), UDNM 411364 . Bar scale is $10 \mathrm{~mm}$.

Occurrence: Upper Campanian. Basal phosphate bed of the Annona Formation, Okay quarry, Okay, Howard County, Arkansas.

Suborder AMMONITINA Hyatt, 1889, p.7 Superfamily DESMOCERATACEAE Zittel, 1895 , p. 426

[nom. transl. Wright and Wright, 1951, p. 18; ex Desmoceratidae Zittel, 1895].

Family DESMOCERATIDAE Zittel, 1895, p. 426

Subfamily DESMOCERATINAE Zittel, 1895, p. 426

[nom. transl. Matsumoto, 1938, p. 190; ex Desmoceratidae Zittel, 1895].

Genus Desmophyllites Spath, 1929, p. 270

[nom. nov. pro. Schlueteria de Grossouvre, 1894, p. 216 non Fritsch in Fritsch and Kafka, 1887, p. 33; = Schluetericeras Collignon, 1938, p. 92 (non Hyatt, 1903, p. 92) (objective synonym)].

Type species: Desmoceras larteti Seunes, 1891, p. 19, pl. 12 (2), fig. 2; pl. 13 (3), figs. 2 , 3 , by subsequent designation by Spath, 1929, p. 46.

Desmophyllites diphylloides (Forbes, 1846)

Plate 1, figs. 1-8; text-fig. 5c,

1846 Ammonites diphylloides Forbes, p. 105, pl. $\mathbf{8}$, fig. 8.

1985 Desmophyllites diphylloides (Forbes, 1846); Henderson and McNamara, p. 54, pl. 4 , figs. $1-4$ (with full synonymy).

Lectotype: $\mathrm{BMNH} \mathrm{C} 22682$, the original of Forbes, 1846 , p. 105, pl. 8, fig 8 , designated by 


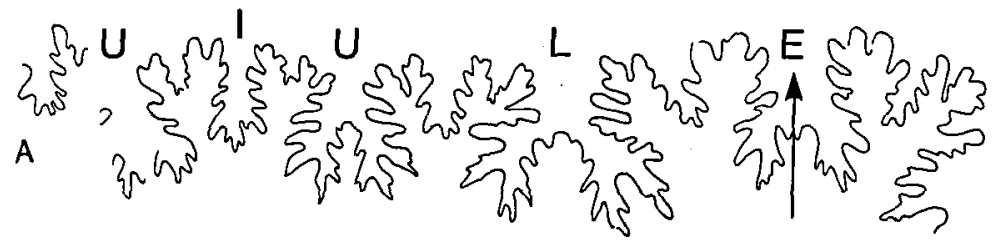

ह

SU⿻

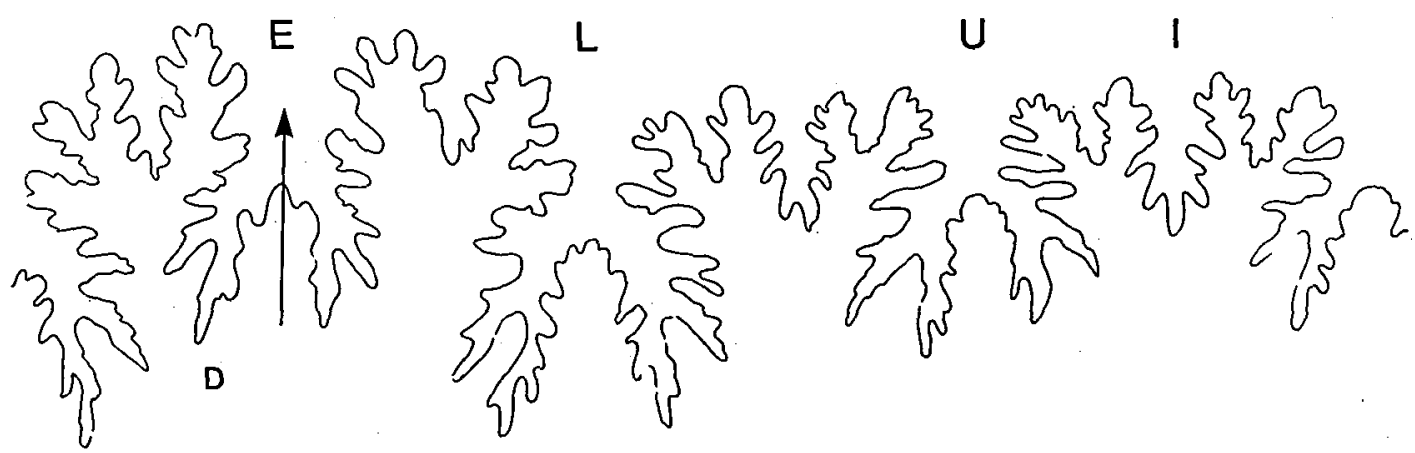

Text-fig. 7. Sutures. A, Nostoceras (Nostoceras) platycostatum, sp. nov., USNM 411348. B, Oxybeloceras crassum (Whitfield, 1877), USNM 411282. C, Didymoceras cochleatum (Meek and Hayden, 1858), USNM 411362. D, Didymoceras mortoni (Hall and Meek, 1856), USNM 411313. Bar scale is $10 \mathrm{~mm}$. 


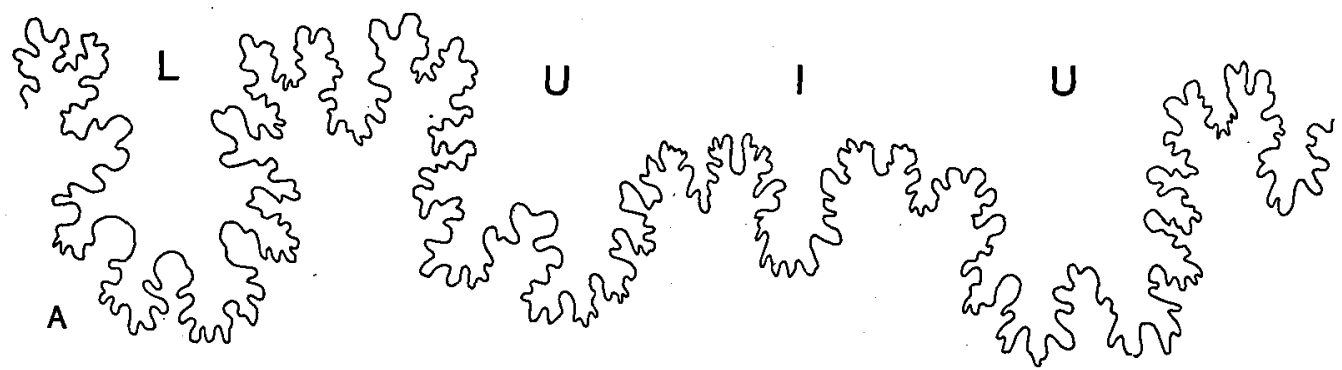

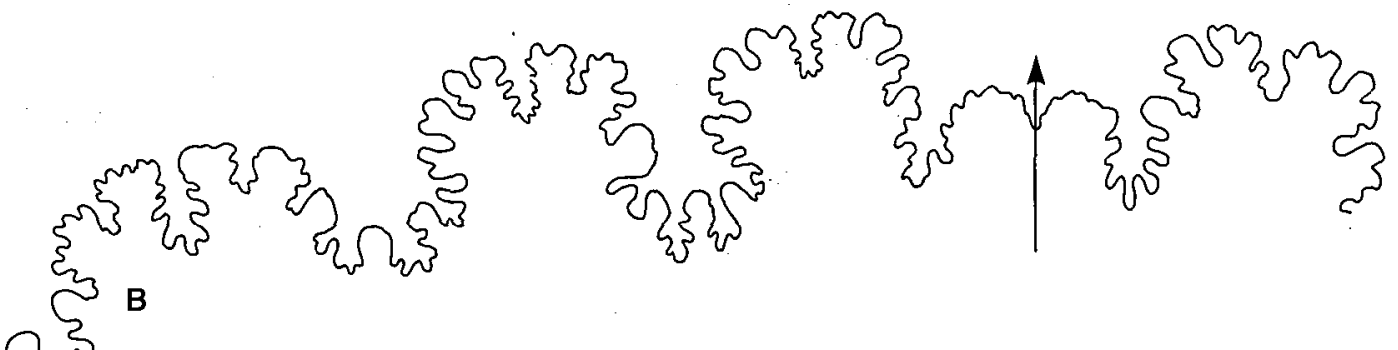
और

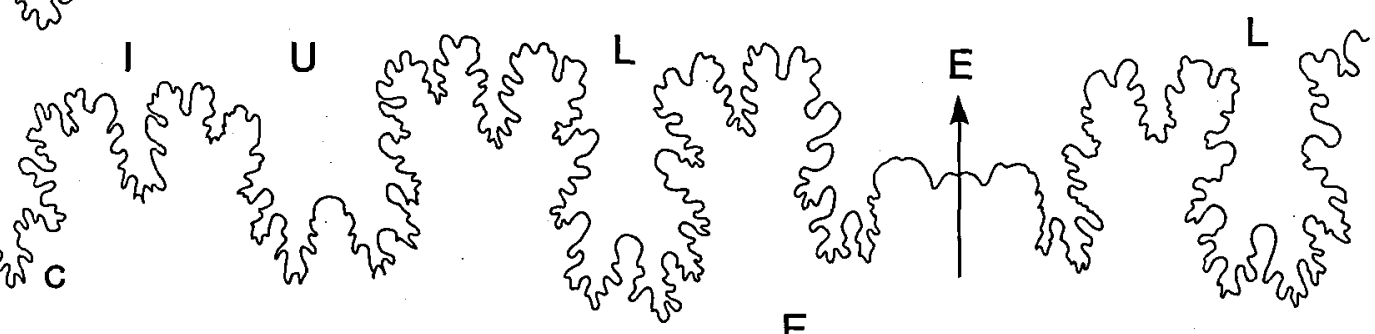

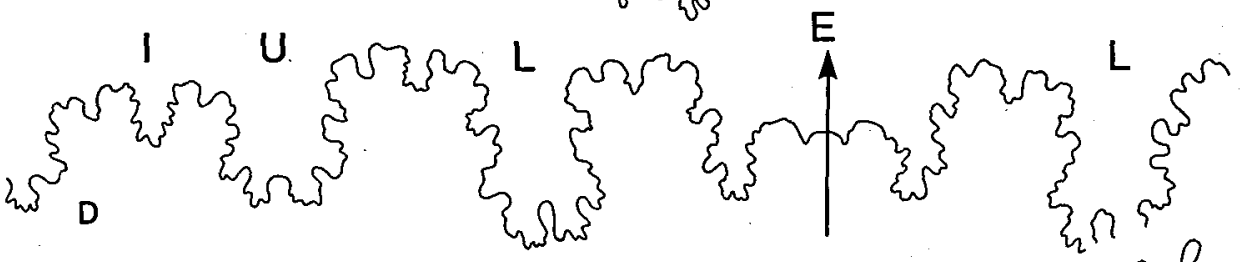
级得
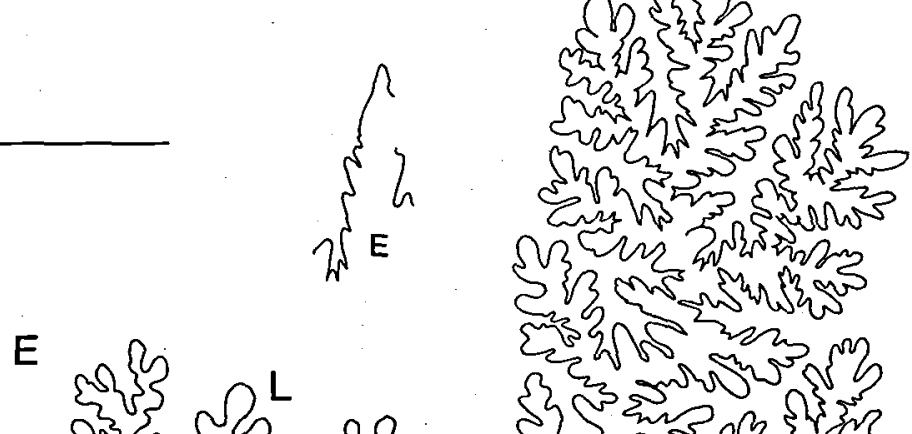

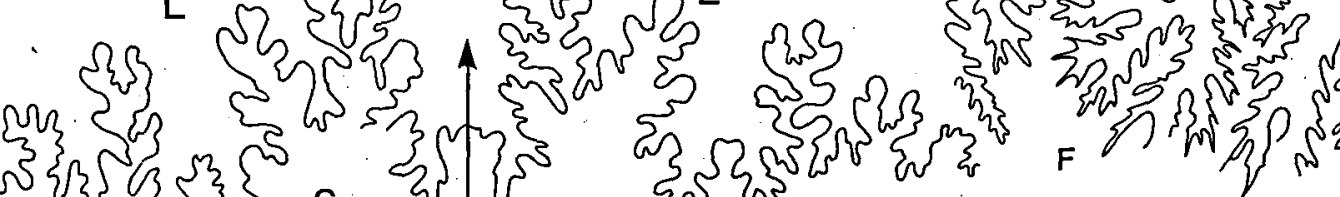

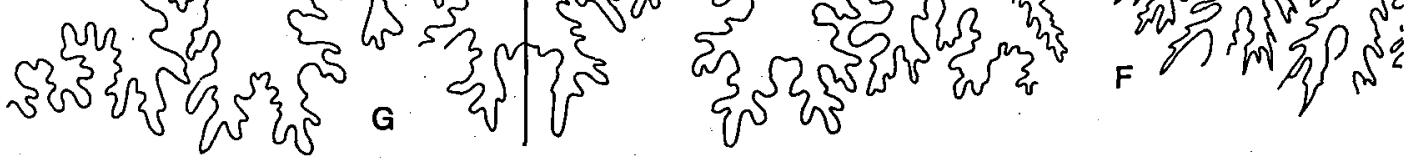

Text-fig. 8. Sutures. A, Baculites reduncus Cobban, 1977, USNM 411301. B, D, Baculites taylorensis Adkins, 1929, USNM 411297 and 411308. C, Baculites sp., USNM 411303. E, F, Pseudophylites sp., USNM 411237. G, Trachyscaphites redbirdensis Cobban and Scott, 1964, USNM 411278. Bar scale is $10 \mathrm{~mm}$. 

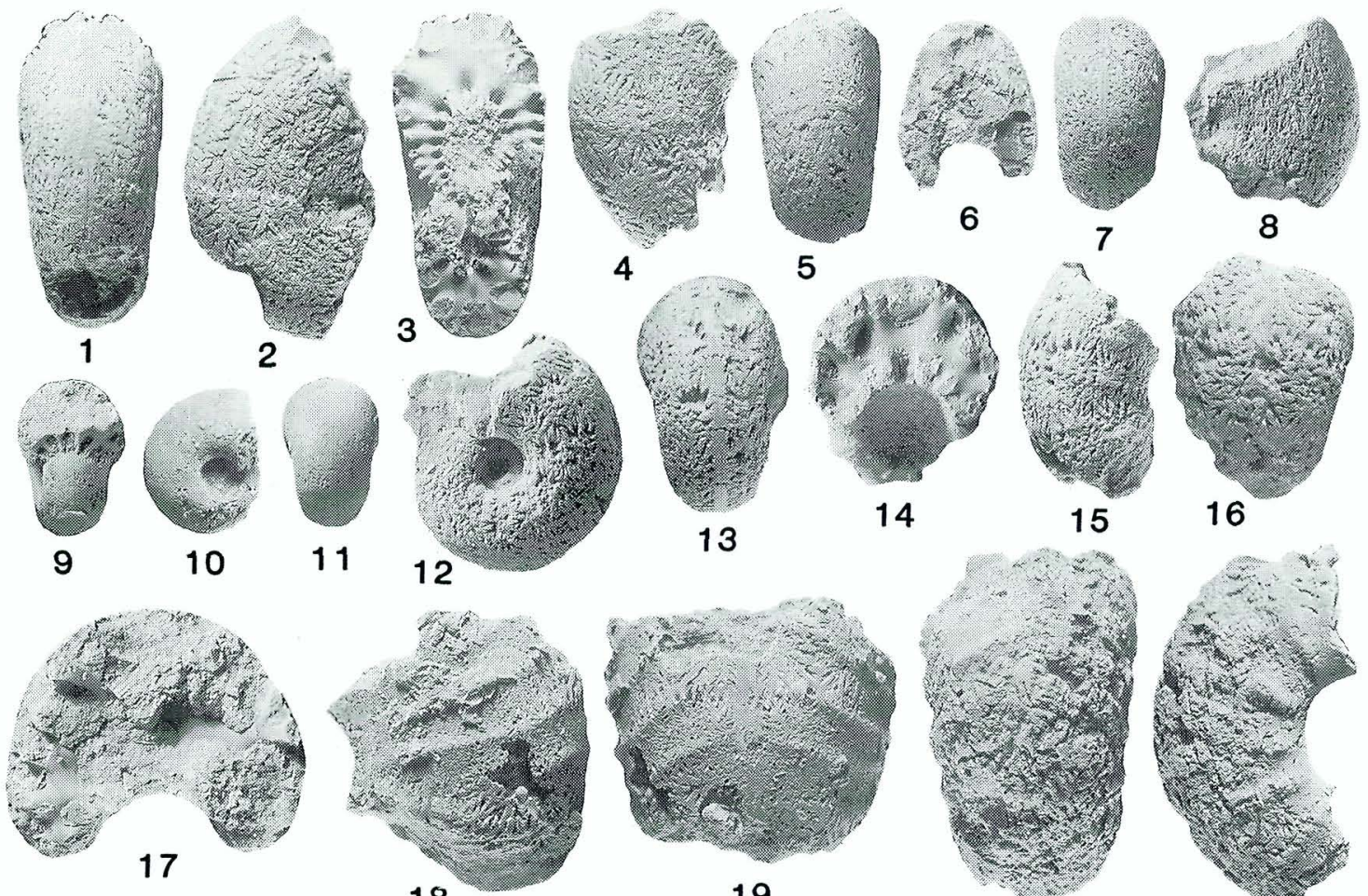

19

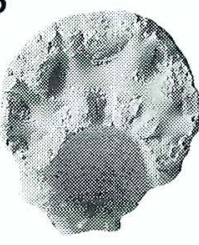

14

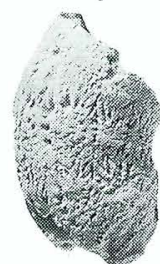

15

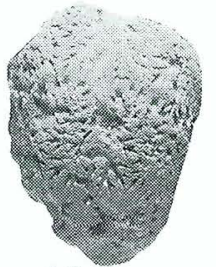

16
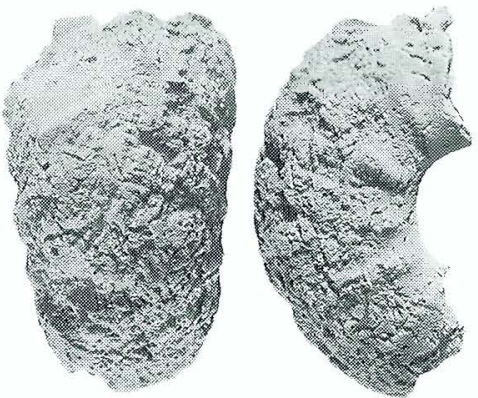

21

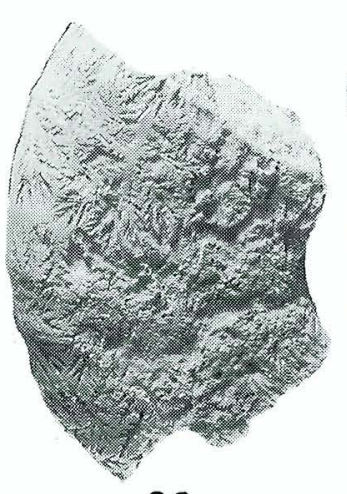

22

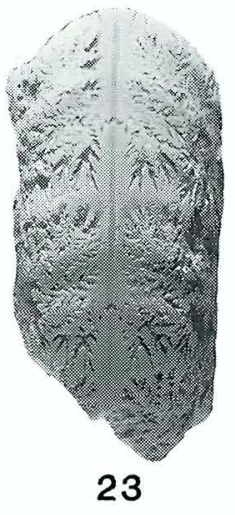

23
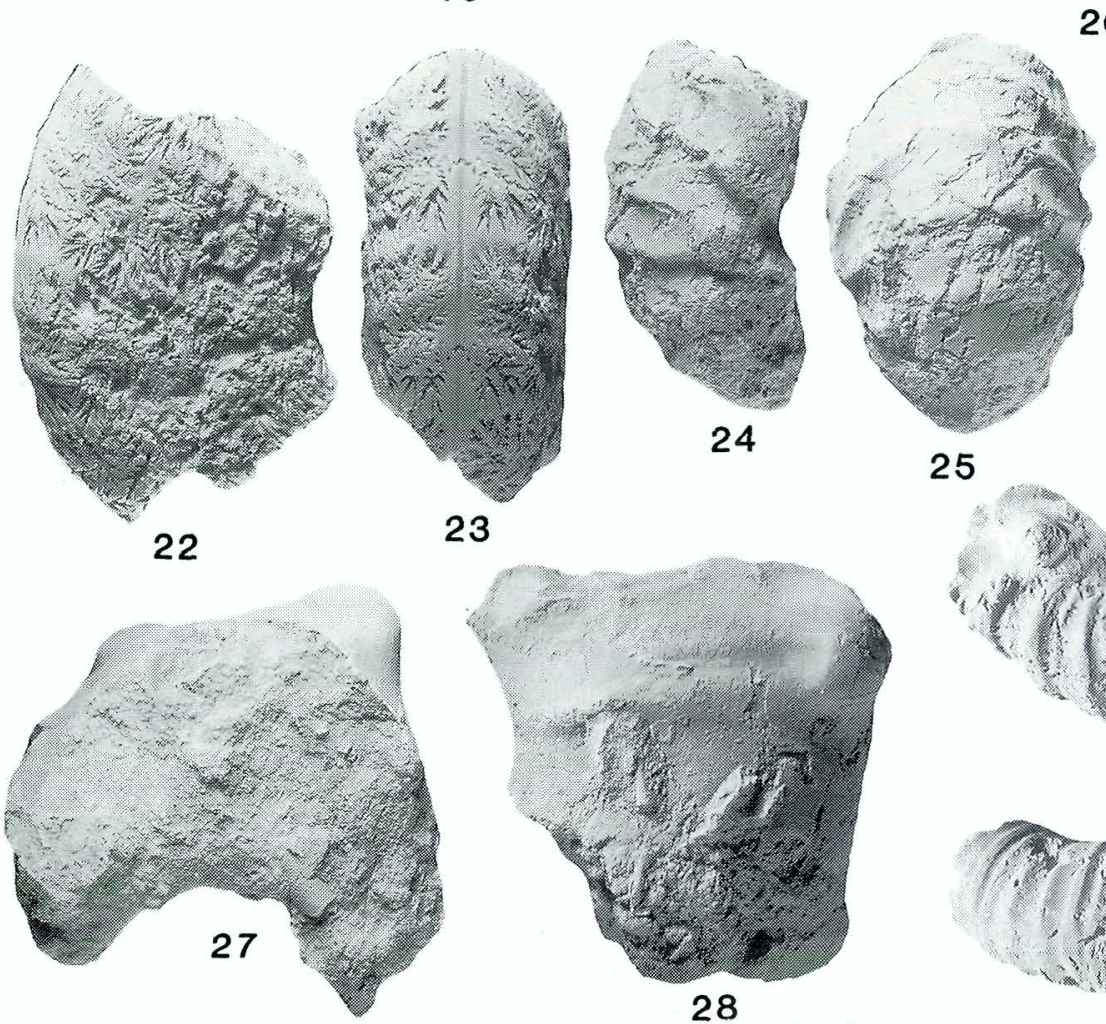

20
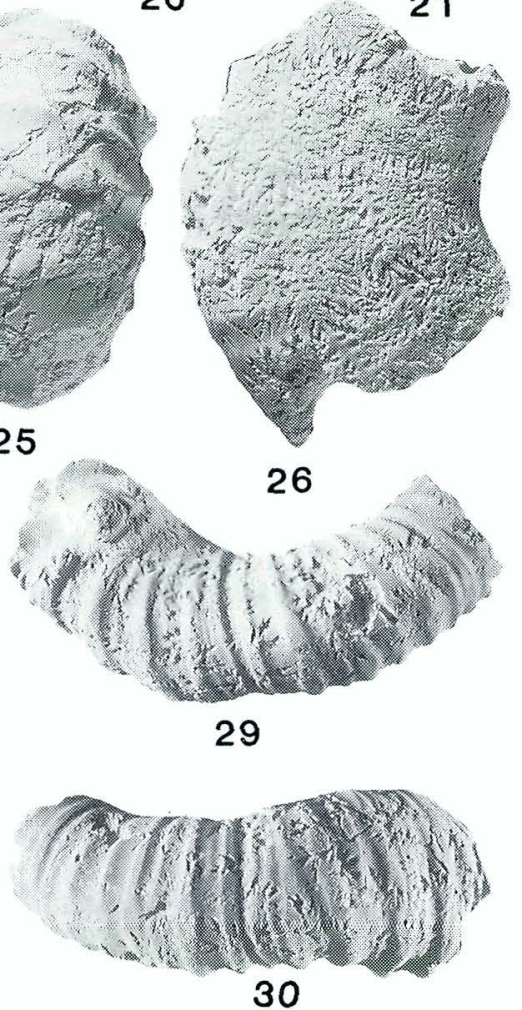

Plate 1. Figs. 1-8 Desmophyllites diphylloides (Forbes, 1846). 1-3, USNM 411259; 4-6, USNM 411258; 7, 8, USNM 411260. Figs. 9-21, 24, 25, 27, 28. Menuites cf. portlocki (Sharpe, 1855). 9-11, USNM 411264; 12, 13, USNM 411271; 14-16, USNM 411270; 17-19, USNM 411263; 20, 21, USNM 411267; 24, 25, USNM 411266; 27, 28, USNM 411269. Figs. 22, 23, 26. Pachydiscus (Pachydiscus) sp. 22, 23, USNM 411262; 26, USNM 411362. Figs. 29, 30. Didymoceras cochleatum (Meek and Hayden, 1859). USNM 411261. All specimens are from the basal phosphate bed of the Annona Chalk at the Okay quarry, Okay, Howard County, Arkansas. All figures are natural size. 
Matsumoto and Obata, 1955 , p. 122; from the Valudayur Beds of Pondicherry, South India.

Description: Three phosphatised fragments have whorl heights of $16-20 \mathrm{~mm}$. Coiling is very involute with a tiny, crater-like umbilicus. The umbilical wall and shoulder are rounded, the whorl section compressed, with a whorl breadth to height ratio of 0.8 , the flanks subparallel and flattened, the ventrolateral shoulders and venter broadly and evenly rounded. The moulds are smooth, except for faint prorsiradiate constrictions that are straight on the flank but form an obtuse ventral chevron. Sutures have deeply incised elements. $\mathrm{E} / \mathrm{L}$ is bifid with narrow stem; $\mathrm{L}$ is deep and trifid, 7 auxiliary saddles are visible on $\mathrm{U}$, which is incompletely preserved.

Discussion: These fragments agree closely with the type material from southern India and specimens from the upper Maastrichtian Miria Formation of western Australia described by Henderson and McNamara (1985). Desmophyllites larteti (Seunes, 1891) (Kennedy and Summesberger, 1984 , p. 156 , pl. 1, fig. 6 ; pl. 2, figs. 1-3, 5-6) is a much larger species, more compressed and with much more flexuous constrictions.

Occurrence: Upper Campanian, basal phosphate bed of Annona Chalk, Okay Quarry, Okay, Howard County, Arkansas. Elsewhere the species is said to range from lower Santonian to upper Maastrichtian, with records from southern France, north Africa, Angola, Zululand (South Africa), Madagascar, southern India, Japan, Sakhalien, Alaska, British Columbia, Washington, California and southern Argentina.

Family PACHYDISCIDAE Spath, 1922a, p. 132 [nom. transl. Spath, 1923, p. 39; ex Pachydiscinae Spath, 1922a]

Genus and Subgenus Pachydiscus Zittel, 1884, p. 466

[=Parapachydiscus Hyatt, 1900 , p. 570; Joaquinites Anderson, 1958, p. 218; Pseudomenuites Matsumoto, 1955, p. 169].

Type species: Ammonites neubergicus Hauer, 1858 , p. 12 , pl. 2 , figs. $1-4$, by the subsequent designation of de Grossouvre, 1894, p. 177.
Pachydiscus (Pachydiscus) sp.

Plate 1, figs. 22, 23, 26

Description and Discussion: More than 20 fragments have whorl heights of between 32 and 58 $\mathrm{mm}$, most are phosphatised, the largest specimen, a distorted phragmocone $140 \mathrm{~mm}$ in diameter is only partially phosphatised. Coiling appears to have been moderately involute with a small, shallow umbilicus, the umbilical wall low and rounded. The whorl section is compressed, with flattened inner and broadly rounded outer flanks, the ventrolateral shoulders are broadly rounded, and the venter is somewhat flattened. Feeble inner flank ribs are visible on some fragments, but the most obvious ornament is low, broad, concave prorsiradiate ribbing on the outer flank, which is flexed forwards and crosses the venter in a broad convexity. The suture, which is deeply and intricately subdivided is typical for the genus. Although indeterminate as to species, these fragments belong to the compressed group of Pachydiscus (Pachydiscus), Campanian examples of which are $P$. (P.) oldhami (Sharpe, 1855) (p. 32, pl. 14, fig. 2) and $P$. (P.) haldemsis (Schlüter, 1867) (p. 19, pl. 3, fig. 1). The present material may well belong to $P$. (P.) travisi (Adkins, 1929) (p. 207, pl. 6, figs. 7-9), originally described from a phosphate bed in the "Taylor formation" of central Texas, a poorly known species with ornament of $P$. (P.) haldernsis type.

Occurrence: Upper Campanian basal phosphate bed of Annona Chalk, Okay quarry, Okay Howard County, Arkansas.

Genus Menuites Spath, 1922b, p. 123

$[=$ Besairieites Collignon, 1931, p. 19]

Type species: Ammonites menu Forbes, 1846, p. 111 , pl. 10, fig. 1 .

Discussion: The type species of Menuites has microconchs as the type series, but the associated macroconch has yet to be recognised. Several other Menuites are demonstrably microconchs of Anapachydiscus Yabe and Shimizu, 1926, while other Anapachydiscus have Urakawites Matsumoto, 1955, as microconchs. 
Menuites cf. portlocki (Sharpe, 1855)

Plate 1, figs. 9-21, 24, 25, 27, 28; text-fig. 5A, B compare

1855 Ammonites portlocki Sharpe, p. 30, pl. 13, figs. 2, 3.

1980 Menuites, portlocki portlocki (Sharpe, 1855); Blaszkiewicz, p. 47, pl. 39, figs. 1, 4, $6,7,9,12 ;$ pl. 40 , figs. 5-8 (with additional synonymy).

1980 Menuites portlocki posterior Blaszkiewicz, p. 48 , pl. 33, figs. 1,2 ; pl. 34 , figs. 5, 6; pl. 39 , figs. $2,3,5,8,10,11$; pl. 40 , figs. $1-4$, 9-11; pl. 41, figs. $1-6$.

Type: Lectotype is no 37247 in the BGS Collections, the original of Sharpe 1855, pl. 13, fig. 2, designated by Wright and Wright, 1951 (p. 36) (Blaszkiewicz, 1980, p. 47, designated the same specimen lectotype in ignorance of the Wrights' act); paralectotype is 37246 in the same collection, the original of Sharpe, 1855, pl. 13, fig. 3. Both are from the upper Campanian White Limestone of Tamlagh, Ulster.

Description: We have 20 fragments that have phragmocone whorl heights of 8.5 to $28 \mathrm{~mm}$. The smallest specimen is a phragmocone $16.5 \mathrm{~mm}$ in diameter. Coiling is involute with a deep conical umbilicus, the umbilical wall rounded and undercut on the mould, the whorl section depressed and reniform with the greatest breadth at midflank, the flanks inflated, the ventrolateral shoulders and venter broadly and evenly rounded. At this stage the mould is smooth, except for a faint suggestion of low, broad undulations. A corroded mould at $27 \mathrm{~mm}$ diameter also lacks obvious ornament, perhaps in part due to wear. It has $\mathrm{U}=38 \%$, and a whorl breadth to height ratio of 1.34. By a whorl height of $16 \mathrm{~mm}$ the whorl breadth to height ratio is 1.31 in USNM 411270 , and ornament has appeared. On larger specimens this takes the form of weak umbilical bullae that give rise to pairs of narrow, distant prorsiradiate ribs that loop across the venter in a broad convexity and weaken markedly over the venter in some cases. Ribbing and tuberculation strengthen markedly on the body chamber. The largest specimen, which has a maximum preserved costal whorl height of $46 \mathrm{~mm}$, shows the style of ornament described above in artificial moulds taken from the dorsum. Distant narrow ribs arise at umbilical bullae and link to massive roundtopped conical ventrolateral tubercles. The juvenile suture is deeply and intricately incised with bifid saddles and trifid lobes.

Discussion: The Arkansas specimens differ from the type specimens only in the somewhat flatter flanks of the largest fragment. This is one of the diagnostic characters ascribed to $M$. portlocki posterior Blaszkiewicz, 1980 (p. 48, pl. 33, figs. 1-2; pl. 34, figs. 5-6; pl. 39, figs. 2-3, 5, 8, 10-11; pl. 40, figs. 1-4, 9-11; pl. 41, figs. 1-6) from the upper Campanian of the Vistula Valley, Poland. Other features separating it from the nominate subspecies are larger size, narrower umbilicus, compressed whorl section, flattened sides to body chamber with flanks and umbilical wall distinctly demarcated, plus a lack of lateroumbilical tuberculation in the late developmental stage. Much of the Polish material seems to be more-or-less deformed and crushed to us and we refer the present material to a broad species, $M$. portlocki.

Occurrence: Upper Campanian, basal phosphate bed of Annona Chalk, Okay quarry, Okay, Howard County, Arkansas. In Europe $M$. portlocki occurs in the upper Campanian of Ulster, Norfolk, England, as well as Germany and Poland.

Superfamily HOPLITACEAE H. Douvillé, 1890 , p. 2190

(nom. correct. Wright and Wright, 1951, p. 21 (pro Hoplitida Spath, 1922b, p. 95, nom. transl. ex. Hoplitida Douvillé, 1890). (=Placenticerataceae Hyatt, 1900, p. 584, nom. correct. Casey, 1960 , p. 208, pro Placenticeratida Hyatt, 1900; Engonocerataceae Hyatt, 1900 , p. 585, nom. transl. Basse, 1952, p. 658, ex Engoniceratidae Hyatt, 1900).

Family PLACENTICERATIDAE Hyatt, 1900, p. 585

(=Hypengonoceratinae Chiplonkar and Ghare, 1976 , p. 2; Baghiceratinae Chiplonkar and Ghare, 1976, p. 3).

Genus Placenticeras Meek, 1876, p. 462

(for synonymy see Kennedy and Wright, 1983, p. 869)

Type species: Ammonites placenta DeKay, 1828, 


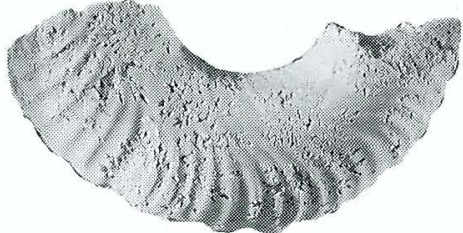

1

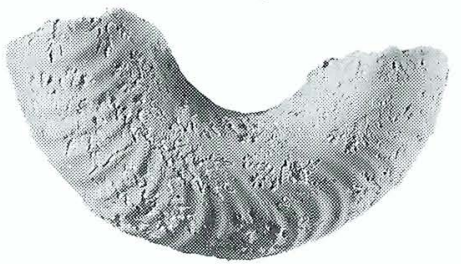

4

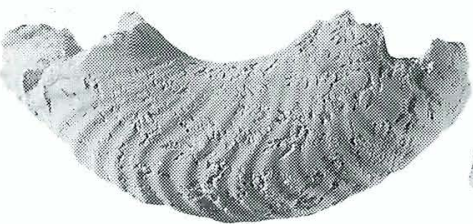

7

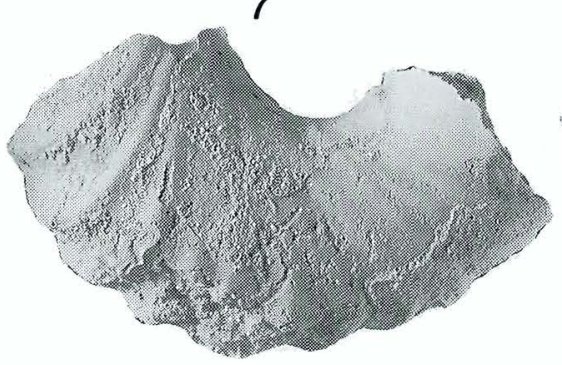

10

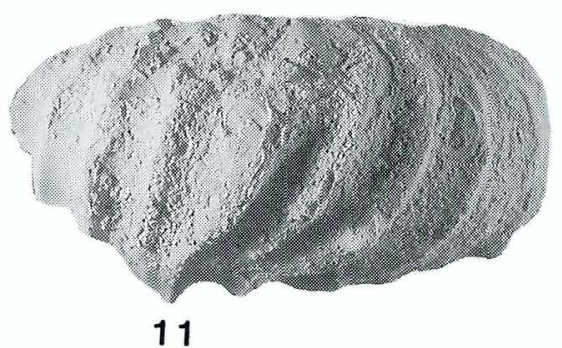

11

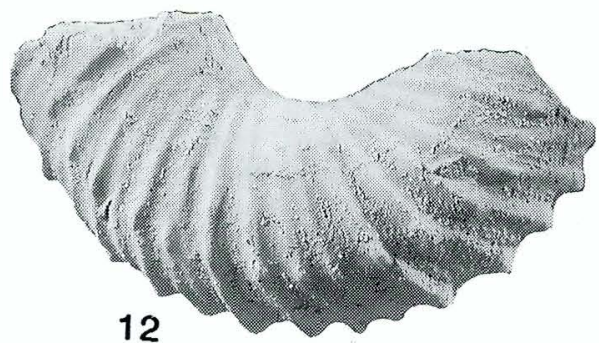

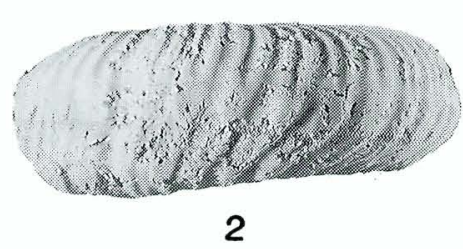

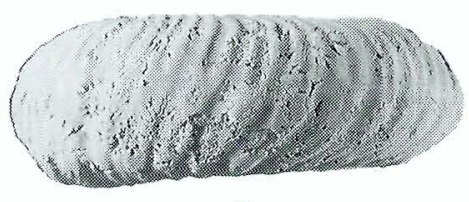

5

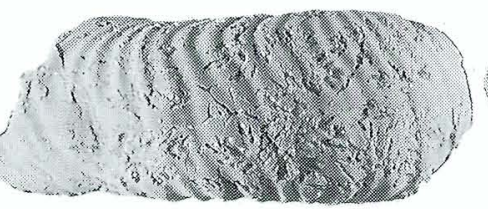

8

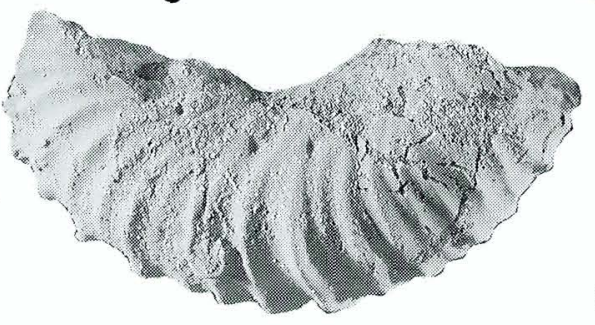

13

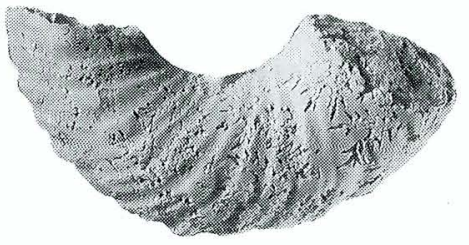

3

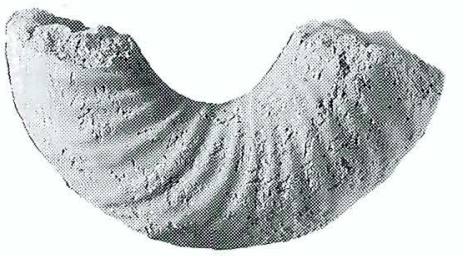

6

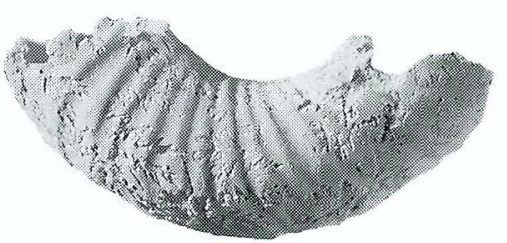

9
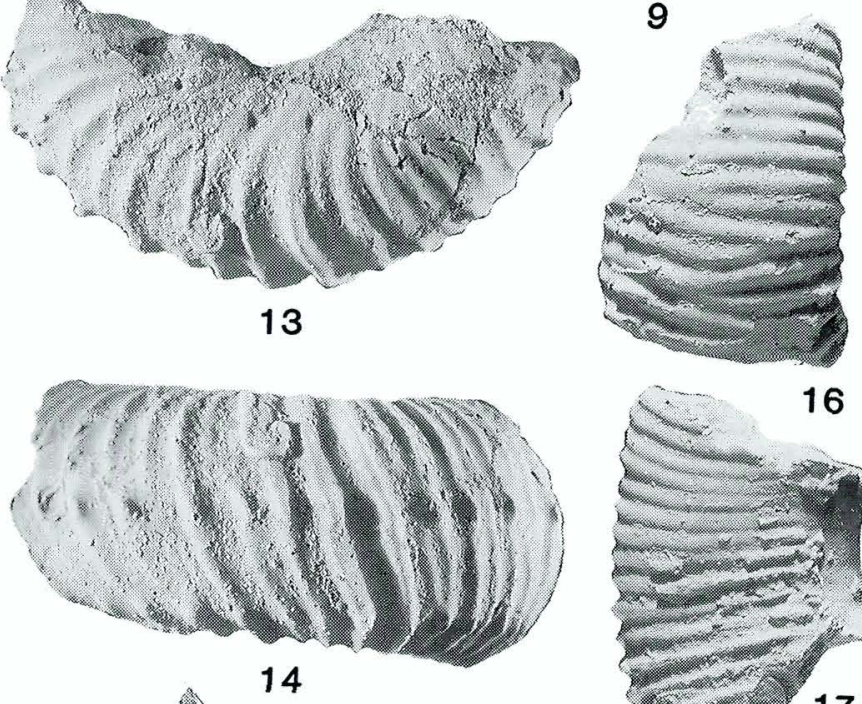

16

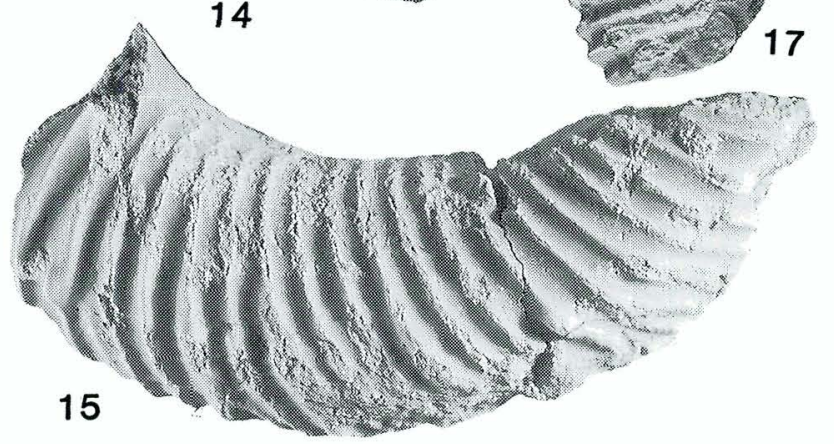

Plate 2. Figs. 1-9. Didymoceras tortum (Meek and Hayden, 1858). 1-3, USNM 411357; 4-6, USNM 411355; 7-9, USNM 411356. Figs. 10-15. Didymoceras cochleatum (Meek and Hayden, 1858). 10, 11, USNM 411366; 12, 13, 14, USNM 411365; 15 , USNM 411367. Figs. 16, 17. Nostoceras (Nostoceras) platycostatum sp. nov. USNM 411328. All specimens are from the basal phosphate bed of the Annona Chalk at the Okay quarry, Okay Howard County, Arkansas. All figures are natural size. 


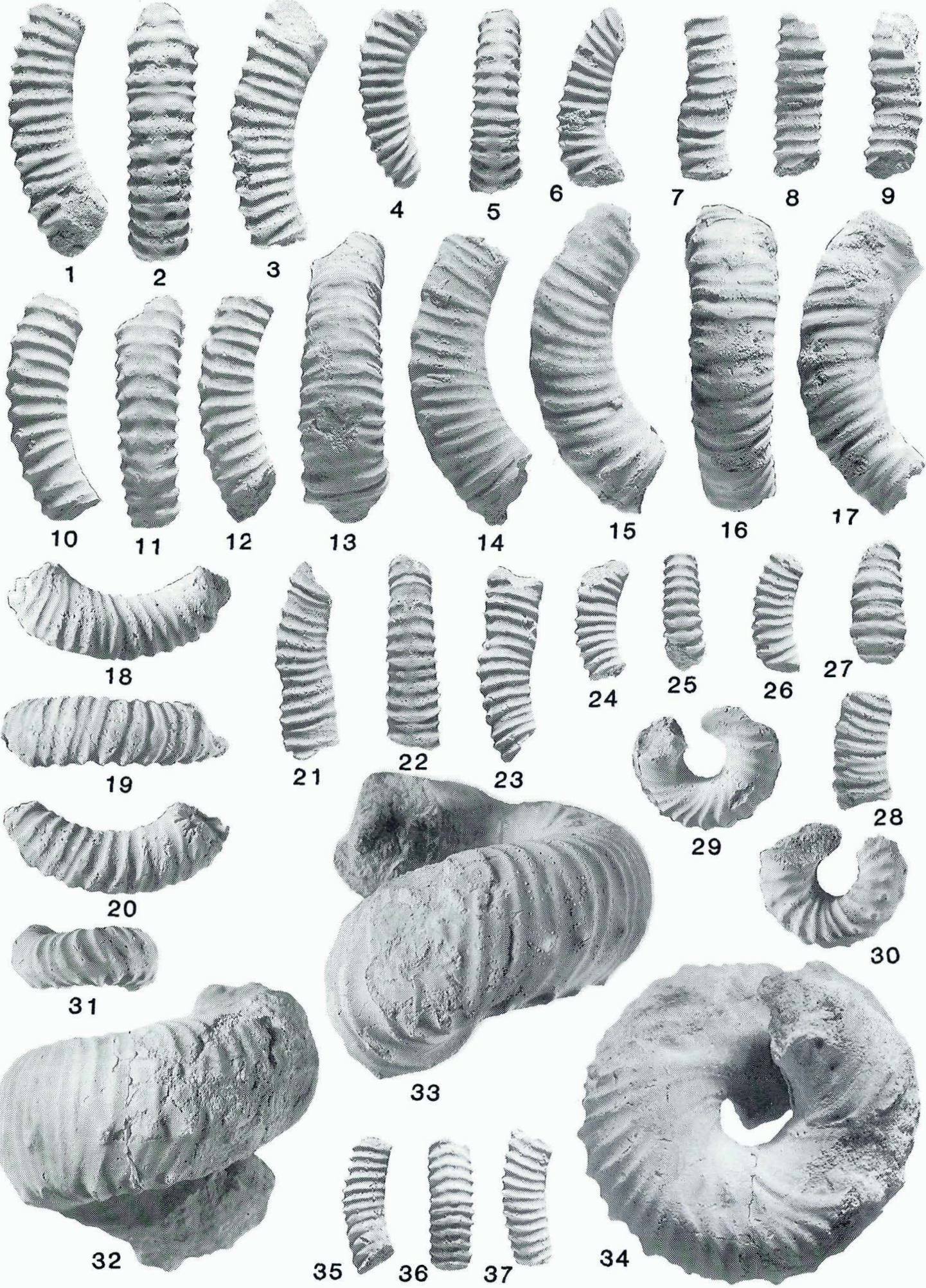

Plate 3. Figs. 1-28, 32-37. Didymoceras mortoni (Hall and Meek, 1856). 1-3, USNM 411315; 4-6, USNM 411310; 7-9, USNM 411314; 10-12, USNM 411312; 13, 14, USNM 411309; 15-17, USNM 411317; 18-20, USNM 411311; 21-23, USNM 411320; 24-26, USNM 411318; 27, 28, USNM 411316; 32-34, USNM 411372; 35-37, USNM 411319. Figs. 29-31. Didymoceras tortum (Meek and Hayden, 1858). USNM 411353. All specimens are from the basal phosphate bed of the Annona Chalk at the Okay quarry, Okay, Howard County, Arkansas. All figures are natural size. 


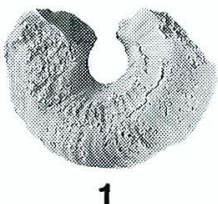

1

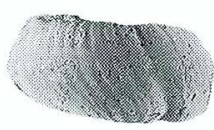

2

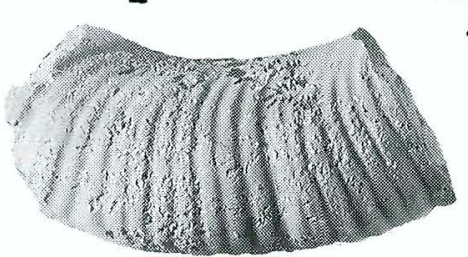

11

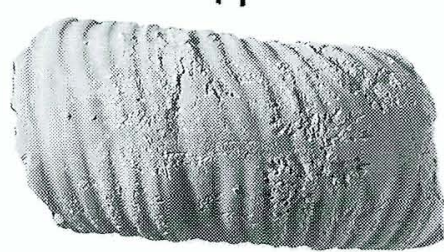

12
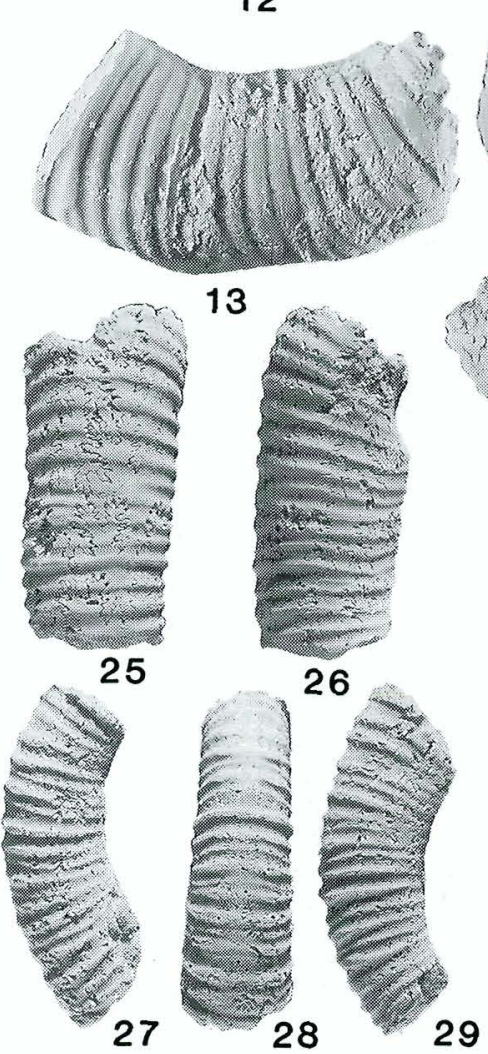

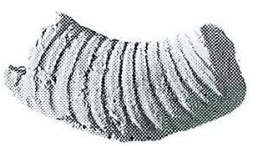

6

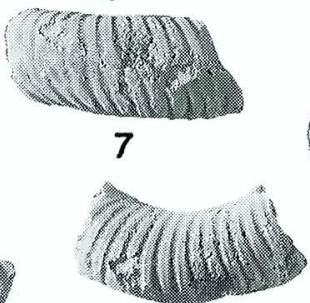

8

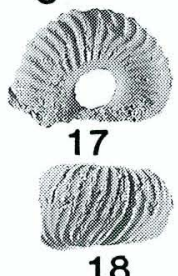

18

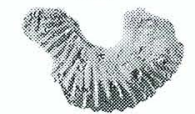

19

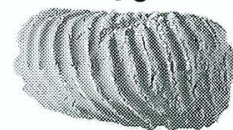

20

15

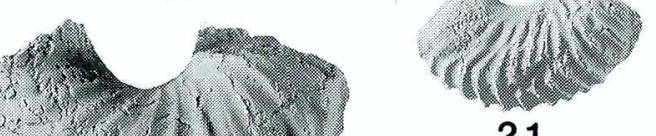

21

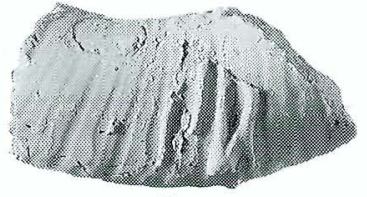

9
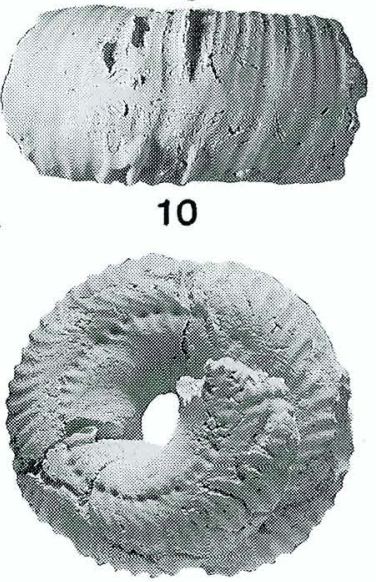

22
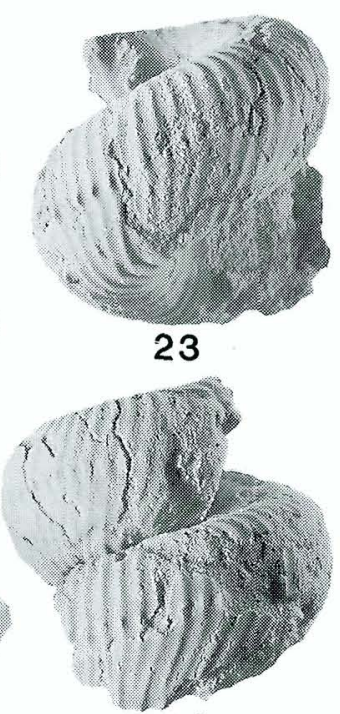

24

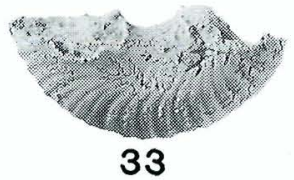

33

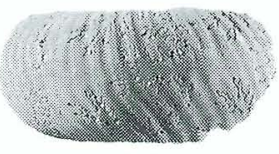

34

Plate 4. Figs. 1-13, 33, 34. Nostoceras (Nostoceras) platycostatum sp. nov. 1, 2, USNM 411349; 3-5, USNM 411326; 6-8, USNM 411327; 9, 10, USNM 411325; 11-13, USNM 411329; 33, 34, USNM 411348. Figs. 14-16. Didymoceras mortoni (Hall and Meek, 1856). USNM 411373. Figs. 17-24, 33-34. Nostoceras (Nostoceras) arkansanus sp. nov. 17, USNM 411335; 18, 19, USNM 411351; 20, 21, USNM 411350; 22-24, USNM 411352. Figs. 25, 26. Didymoceras sp. USNM 411361. Figs. 27-32. Didymoceras cochleatum (Meek and Hayden, 1858). 27-29, USNM 411363; 30-32, USNM 411313. All specimens are from the basal phosphate bed of the Annona Chalk at the Okay quarry, Howard County, Arkansas. All figures are natural size. 


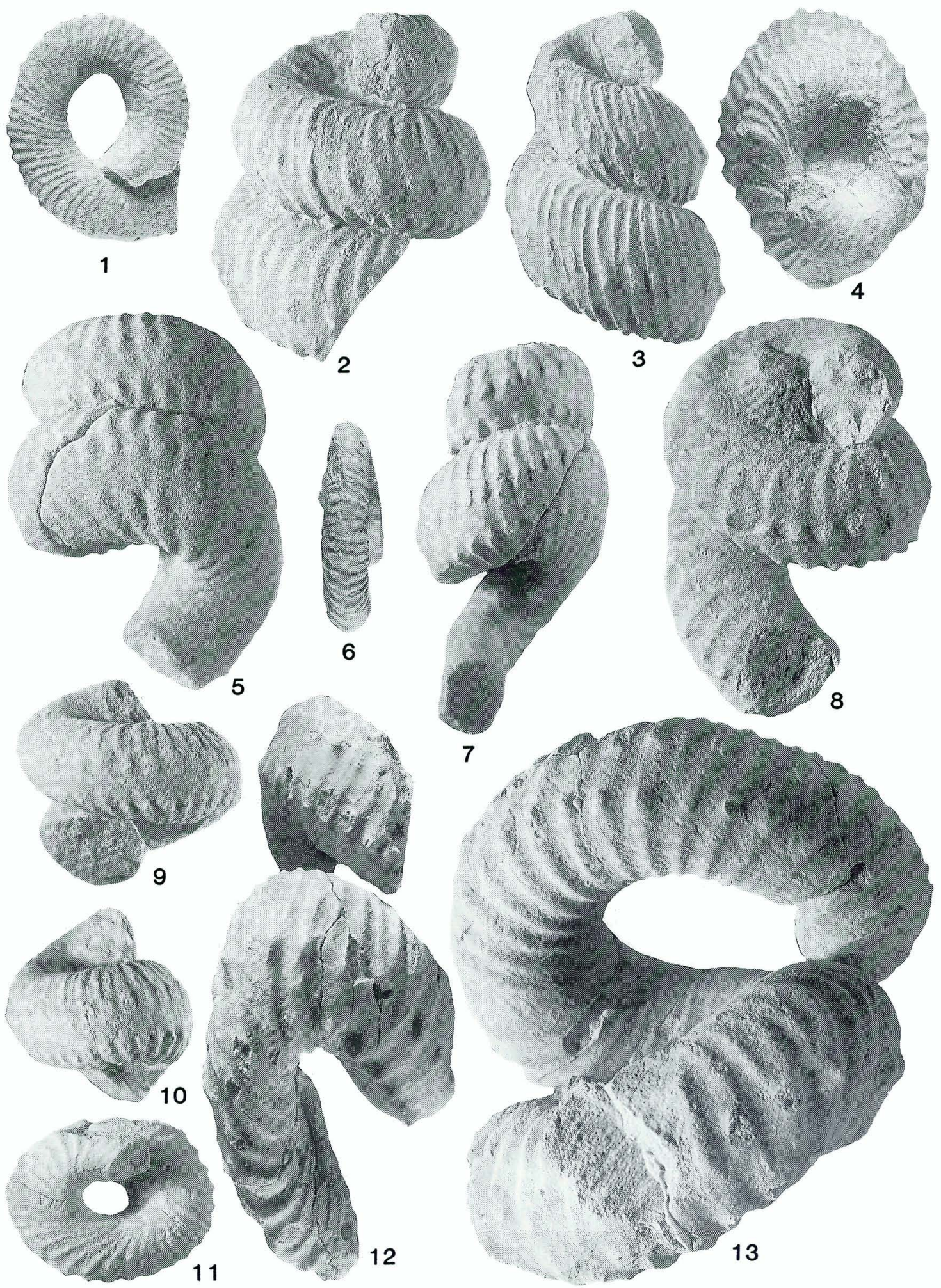

Plate 5. Figs. 1-4, 6, 9-13. Didymoceras donezianum (Mikhailov, 1951). 1, 6, USNM 411346; 2-4, USNM 411378; 9-11, USNM 411375; 12-13, USNM 411376. Figs. 5, 7, 8. Nostoceras (Nostoceras) archiacianum (d'Orbigny, 1842). USNM 411380. All specimens are from the top of the Ozan Formation, Okay quarry, Okay, Howard County, Arkansas. All figures are natural size. 
p. 278 , by original designation by Meek, 1876, p. 426.

\section{Placenticeras sp.}

Discussion: Two fragments, USNM 411268 and 411331, 32 and $36 \mathrm{~mm}$ long, preserve the venter and ventrolateral shoulder of a very compressed Placenticeras species. The venter is narrow, the ventrolateral shoulders sharp, and ornamented by delicate clavi that alternate on either side of the venter. It is specifically indeterminate.

Occurrence: Upper Campanian, basal phosphate bed of Annona Chalk, Okay quarry, Okay, Howard County, Arkansas.

Suborder ANCYLOCERATINA Wiedmann, 1966 , p. 54

Superfamily TURRILITACEAE Gill, 1871, p. 3 Family NOSTOCERATIDAE Hyatt, 1894, p. 568

[=Jouaniceratidae Wright, 1952, p. 218; Bostrychoceratinae Spath, 1953, p. 16;

Emperoceratinae Spath, 1953, p. 17; Hyphantoceratinae Spath, 1953, p. 16].

Genus and subgenus Nostoceras Hyatt, 1894, p. 569

Type species: Nostoceras stantoni Hyatt, 1894, p. 569 , by original designation.

Nostoceras (Nostoceras) archiacianum (d'Orbigny 1842)

Plate 5, figs. 5, 7, 8

1842 Turrilites archiacianus d'Orbigny, p. 607, pl. 148, figs. 5,6 .

1986. Nostoceras (Nostoceras) archiacianum (d'Orbigny, 1842); Kennedy, p. 90, textfigs. $31 \mathrm{~b}-\mathrm{e}, \mathrm{h}$, i (with full synonymy).

Type: Holotype, by monotypy, is MNHP R1192 ex d'Orbigny Collection no. 7212, from the bed with Radiolites crateriformis at Royan (CharenteMaritime), France.

Description: Three fragments are referred to the species. The best-preserved consists of 1.5 whorls of the spire and part of an uncoiled body chamber. The whorls of the spire are barely in contact. Ribs are weak on the upper whorl face but sweep back across the juncture of upper and outer whorl faces in a broad convexity, strengthening and passing obliquely across the outer whorl face. They are strong on the lower whorl face. The ribs total 32 per whorl. All but one or two of the ribs are single, and bear strong equal tubercles about one third way down the outer whorl face. Ribbing effaces markedly across the middle of the flanks between the upper row of tubercles and a lower row, just above the juncture of lower and outer whorl faces, but visible above the succeeding whorl. The incomplete body chamber is bituberculate, with simple ribbing throughout. In two instances only, a pair of ribs link at a tubercle on the upper row.

Discussion: The very simple ribbing and tuberculation, weakening of ribs between the tubercles and overall rib count match that of the Nostoceras (Nostoceras) sp. of Kennedy and Summesberger $(1984$, p. 163, pl. 9, figs. 1, 2, 3, 9) from the upper Campanian of the Gschliefgraben, Upper Austria. Kennedy (1986, p. 90, text-fig. $31 \mathrm{~b},-\mathrm{e}, \mathrm{h}, \mathrm{i})$ showed these to be referrable to the poorly known Nostoceras archiacianum (d'Orbigny, 1842) (p. 607, pl. 148, figs. 5, 6) from the upper Campanian of Royan, Charente-Maritime, France. The simple ribbing and tuberculation of this species is quite unlike that of any of the nostoceratids from the phosphate fauna described here, resembling only Didymoceras cochleatum, but this has constrictions and ribs that loop between tubercles. Differences from European material with which this species has been confused are reviewed by Kennedy (1986, p. 92).

Occurrence: Upper Campanian, uppermost Ozan Formation at the Okay quarry, Okay, Howard County, Arkansas. The species occurs in the upper upper Campanian of Charente-Maritime, France and the Ultrahelvetic, Gschliefgraben, Upper Austria.

Nostoceras (Nostoceras) arkansanum sp. nov. Plate 4, figs. 17-24, 33, 34

Types: Holotype is USNM 411352, paratypes USNM 411335., 411350, 411351, from the upper Campanian phosphate bed at the base of the Annona Chalk at the Okay quarry, Okay, Howard County, Arkansas. 
Diagnosis: Helicoid whorls in contact throughout, ornamented by numerous fine ribs, $50-55$ per whorl, oblique and sinuous on the outer whorl face, with a row of bullate tubercles on the upper third of the exposed whorl face and a second row at the juncture of outer and lower whorl faces. There are an estimated 3-4 constrictions per whorl.

Description: The apical angle is low, and the whorls are just in contact throughout. The holotype (Pl. 4, figs. 22-24), consists of 1.25 whorls that have a maximum preserved whorl height of $17 \mathrm{~mm}$. So far as is known the upper whorl face is flattened with small pits to accommodate the tubercles of the previous whorls. Smaller paratypes may have feebly concave upper whorl surfaces. Ornament is very weak on the inner half of the upper whorl surface, but strengthens with growth; this ornament is markedly concave and sweeps back over the outer part. On the outer whorl face, the ribs are oblique, feebly sinuous, sharp and narrower than the interspaces. The great majority of the ribs are single throughout their course, but a few join in pairs at the base of the outer whorl face. All ribs bear tiny bullae one third of the whorl height below the upper. whorl suture, and a second row at the juncture of outer and lower whorl faces. On the lower whorl face, the ribs are markedly convex, and stronger than on the upper face. Broad constrictions, estimated at 3-4 per whorl, are flanked by slightly strengthened ribs. Sutures not seen.

Discussion: The presence of tubercles and wellmarked constrictions separates this species from Nostoceras (Nostoceras) platycostatum sp. nov., described below, while the translation rate is higher in $N$. arkansanum, and details of ribbing quite different on the mould. The most obvious comparisons are with Nostoceras colubriformis (Stephenson, 1941) (p. 412, pl. 81, figs. 1-3) which is a much smaller species that has the two rows of tubercles close together with the upper row well below the mid-point of the world. The constrictions are much more conspicuous, and many more of the ribs join in pairs at the bottom of the lower whorl face. $N$. colubriformis is from a much higher horizon than $N$. arkansanus, and may well be a descendant.
Occurrence: As for types.

Nostoceras (Nostoceras) platycostatum $\mathrm{sp}$. nov. Plate 2, figs. 16, 17; Plate 4, figs. 1-13, 33, 34; text-fig. 7A

Types: Holotypes is USNM 411329, paratypes USNM 411325-8, 411330-411344 from the upper Campanian phosphate bed at the base of the Annona Chalk, Okay quarry, Okay, Howard County, Arkansas.

Derivative of name: Platys (Greek) flat, in reference to the form of the ribs on the mould.

Diagnosis: Early helicoid whorls in contact, later whorls free, with low translation rate. Ornamented by even, broad, simple, flat-topped annular prorsiradiate ribs on mould, sharp and narrow on shell, only rarely bifurcating. III-defined constrictions are occasionally developed.

Description: The smallest specimen, USNM 411327, has a whorl height of $10 \mathrm{~mm}$; its upper whorl face shows an impressed zone that indicates the whorls were in contact at this size; all other specimens lack such a zone and indicate a loose open helix. Larger fragments show almost no asymmetry, which suggests a very low translation rate or even planispiral late whorls to the late phragmocone and body chamber. Ribs are very weak on the dorsum, but strengthen across the upper whorl face, and are oblique and feebly flexuous on the outer whorl face. Most ribs are simple, but occasional bifurcations occur. On moulds the ribs are low, flat, broad and separated by narrow interspaces; some develop a distinctive flat top and median groove. Where phosphatised shell survives, the ribs are high, thin and narrow as the ornament was produced mainly by thickening the shell, rather than by corrugating it.

The smallest specimen seen shows what may be an irregular constriction, but these are not conspicuous on larger specimens. The largest paratype, USNM 411328 is part body chamber, at a whorl height of $30 \mathrm{~mm}$. The suture has deeply incised bifid saddles that are narrow-stemmed and deeply incised, splayed bifid lobes.

Discussion: Absence of tubercles differentiates 

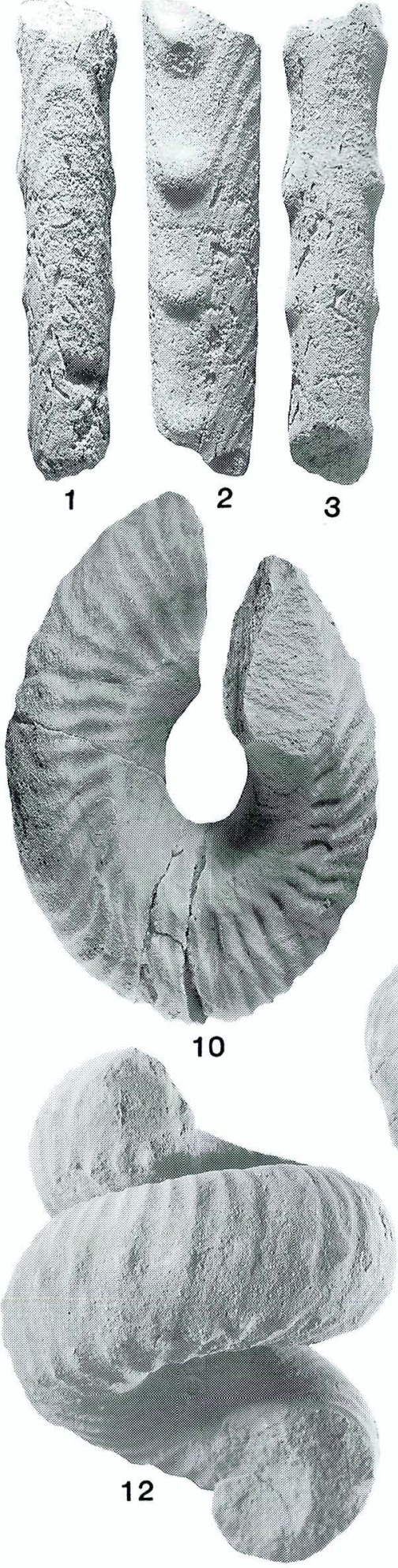

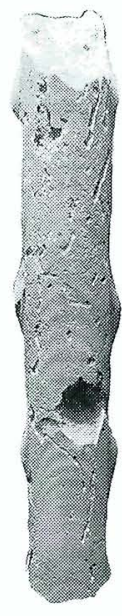

4

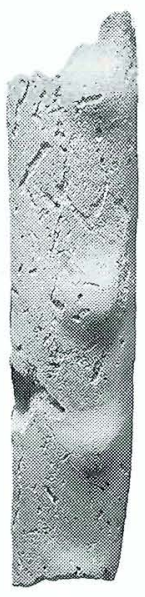

5
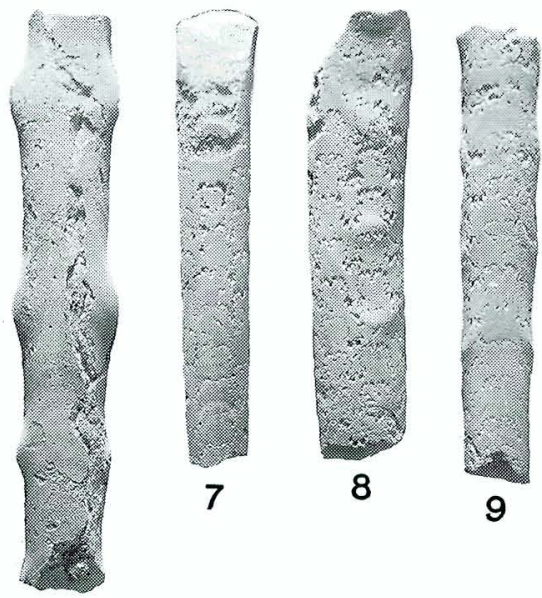

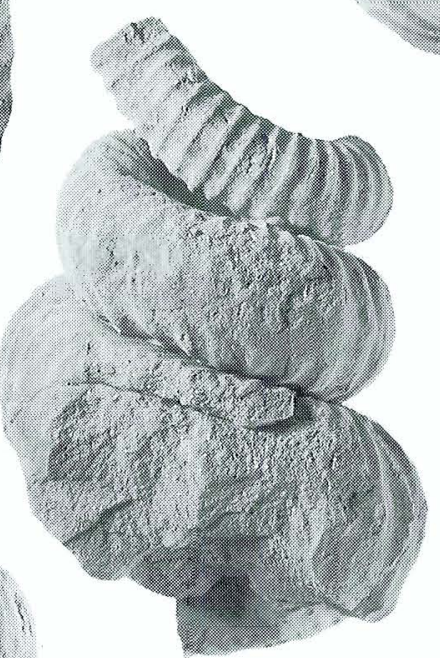

13

\section{6}
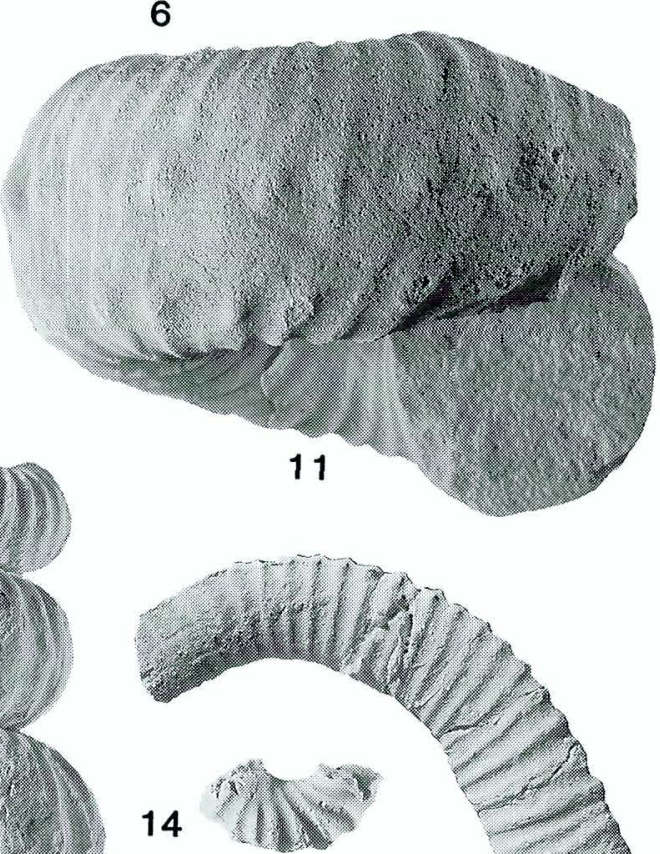

15
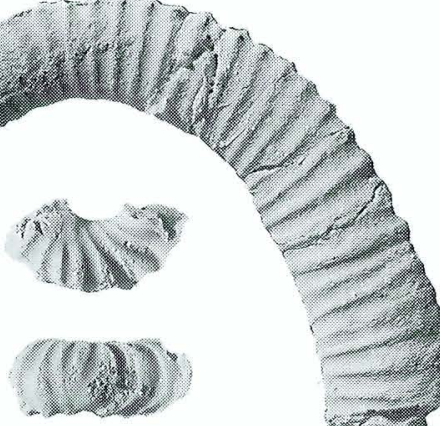

16

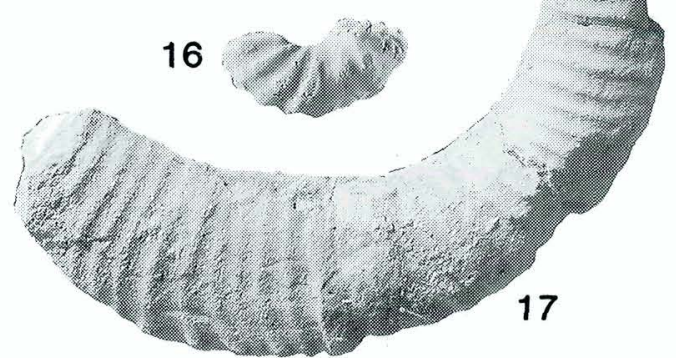

Plate 6. Figs. 1-9. Baculites taylorensis Adkins, 1929. 1-3, USNM 411298; 4-6, USNM 411294; 7-9. USNM 411293. All are from the basal phosphate bed of the Annona Chalk. Figs. 10-13. Didymoceras donezianum (Mikhailov, 1951). 10, 11, USNM 411379; 12 , USNM 411377; 13, USNM 411344. All are from the top of the Ozan Formation. Figs. 14-16. Nostoceras (Nostoceras) tortum (Meek and Hayden, 1858). USNM 411359. From the basal phosphate bed of the Annona Chalk. Fig. 17 Neancyloceras cf. bipunctatum (Schlüter, 1872). USNM 411374, from the top of the Ozan Formation. All specimens are from the Okay quarry, Okay, Howard County, Arkansas. All figures are natural size. 
$N$. platycostatum from most described Nostoceras species, and sets it apart from all other species in the fauna at Okay. It is close to Nostoceras saundersorum (Stephenson, 1941) (p. 417, pl. 83, figs. $6-8$ ), but that species has the whorls in contact throughout with strong, deep, regularly spaced constrictions and associated collar ribs, as well as numerous bifurcations of ribs at the base of the outer whorl surface.

Occurrence: As for types.

Genus Didymoceras Hyatt, 1894, p. 573

[=Emperoceras Hyatt, 1894, p. 575; ? Cirroceras

Conrad, 1868, p. 730 (nomen dubium)].

Type species: Ancyloceras nebrascence Meek and Hayden, 1856 , p. 71 , by original designation.

Didymoceras tortum (Meek and Hayden, 1858)

Plate 2, figs. 1-9; Plate 3, figs. 29-31; Plate 6,figs. 14-16; text-figs. 6B; $9 \mathrm{~A}, \mathrm{~B}, \mathrm{I}-\mathrm{N}$

1859 Helicoceras tortus Meek and Hayden, p. 54.

1859 Helicoceras? tortus Meek and Hayden; Hayden, p. 685.

1860 Helicoceras tortum Meek and Hayden; Meek and Hayden, p. 421.

1864 Heteroceras tortum Meek and Hayden; Meek, p. 25.

1876 Heteroceras tortum Meek and Hayden; Meek, p. 481, pl. 22, fig. 4.

1894 Didymoceras tortum Meek and Hayden; Hyatt, p. 574.

1910 Heteroceras (Didymoceras) tortum Meek and Hayden; Grabau and Shimer, p. 207, figs. $1477-1479$.

1921 Heteroceras (Didymoceras) tortum Meek and Hayden; Grabau, fig. 1754g.

1921 Didymoceras tortum Meek sp.; Spath, p. 253 , footnote.

?1933 Heteroceras tortum Meek and Hayden; Elias, p. 313, pl. 42, fig. 2.

Type: Holotype by monotypy in USNM 471, from the "Great Bend of the Missouri below Fort Pierre ... from the lower part of the Fort Pierre Group", that is to say from the Gregory Shale Member of the Pierre Shale, upper Campanian, Baculites gregoryensis zone.

Description: This is a relatively common species in the phosphatic fauna. Coiling is both dextral and sinistral with the whorls not in contact. A series of juveniles show the coiling to a shell diameter of $25 \mathrm{~mm}$. The whorl section is circular. Ribs are weak on the inside of the whorl, but strengthen across the upper surface, where they are markedly prorsiradiate and number 26-28 per whorl. On the outer whorl surface the ribs are oblique and sweep forward over the juncture of the outer and lower whorl faces, where they are strong and concave on the lower whorl face. Ribs may be single, or branch at the juncture of the outer and lower whorl faces. Ribs bear a flattopped bulla around mid-flank and a weaker bulla at the juncture of outer and lower whorl faces. In a few cases the upper bulla may link a pair of ribs, or a nontuberculate rib may be present between tuberculate ones. Later growth stages are represented only by fragments that suggest an open helical coil. Ornament is subdued. Ribs are weak on the upper whorl face and sweep forward over the juncture with the outer whorl face, where they are markedly convex. They are low, broad and oblique on the outer whorl face. Low blunt circular tubercles below mid-flank link pairs or ribs; nontuberculate ribs are present between tuberculate groups. Blunt bullae are present at the juncture of outer and lower whorl faces and may be linked by a rib or pair of ribs to the upper row of tubercles, or may link to a rib lacking the upper row. Ribs are strong and convex on the lower whorl face. Rather irregular periodic constrictions develop on larger fragments. The suture is deeply incised with bifid lobes; $L$ is large and deep.

Discussion: The coarse simple ribbing and tuberculation of juvenile Didymoceras tortum distinguish it from the Nostoceras species in the phosphatic fauna at Okay. Larger fragments differ from Didymoceras mortoni in their greater expansion rate, irregular position of tubercles, the lesser tendency of ribs to loop and the presence of nontuberculate flank ribs. The ornament is generally much more subdued on moulds. In $\mathrm{Di}$ dymoceras cochleatum (Meek and Hayden, 1858) (p. 55; Meek, 1876, p. 478, pl. 22, fig. 2) the coiling appears to have been in a much more open helix, with, presumably, a lower apical angle. It is a rather evenly ribbed form, with tubercles of variable size in two rows, and nontuber- 

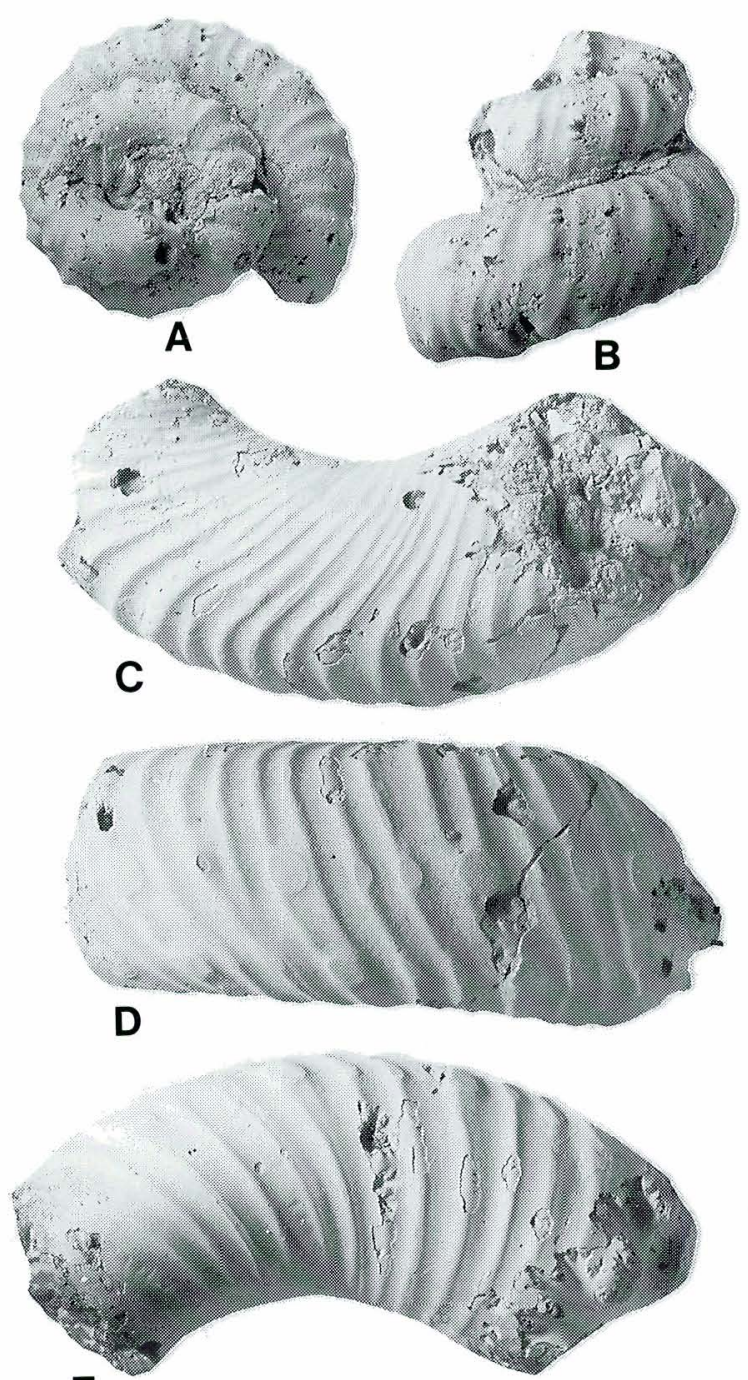

$\mathbf{E}$
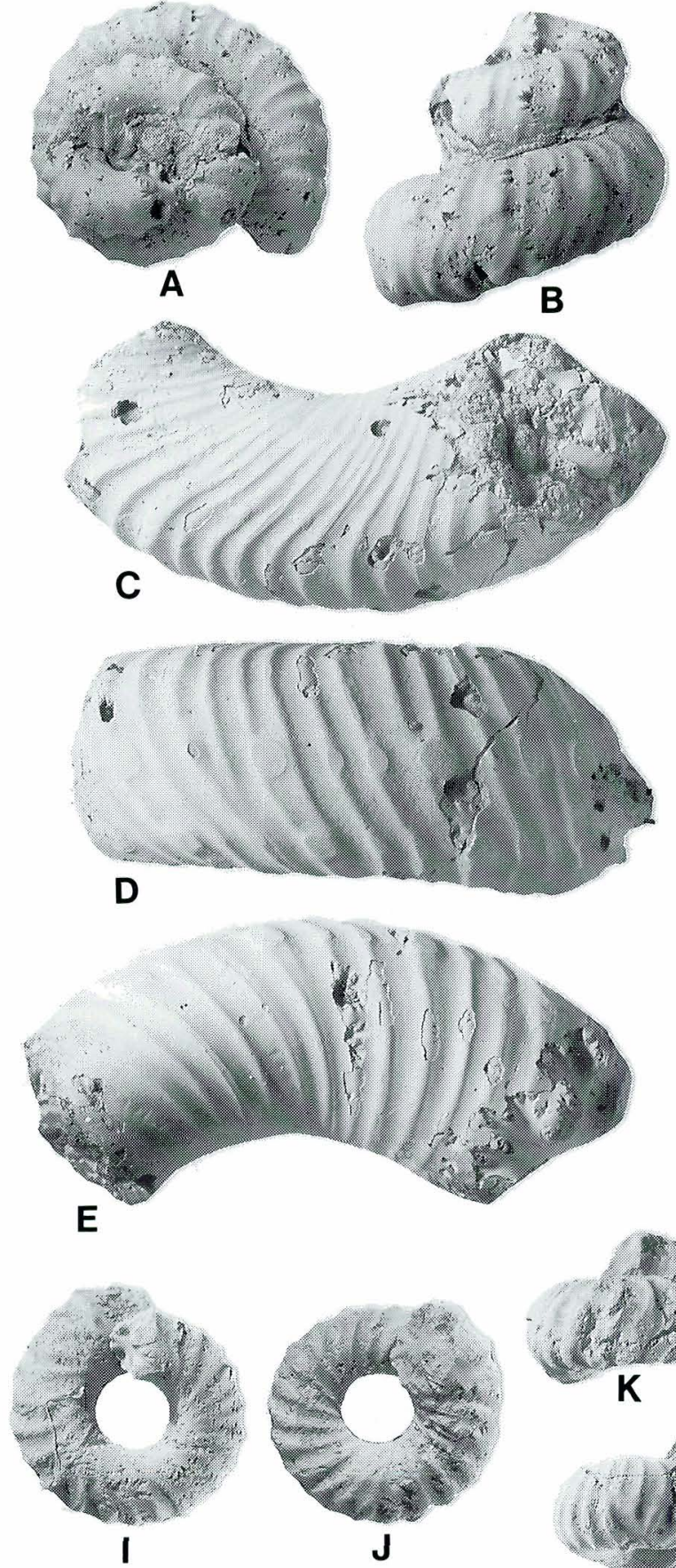
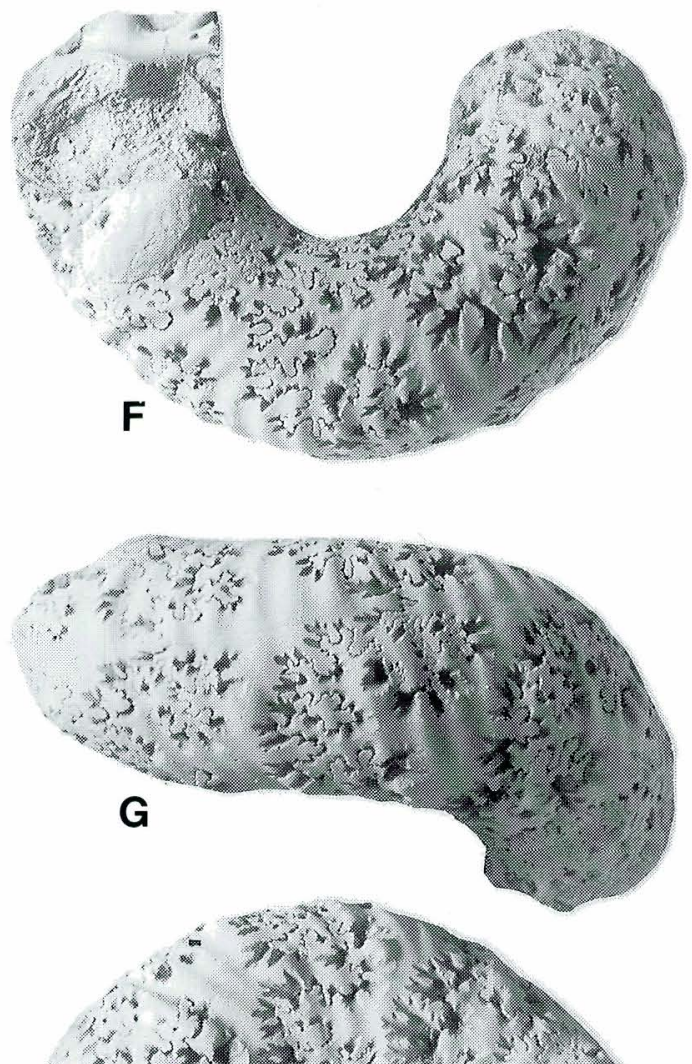

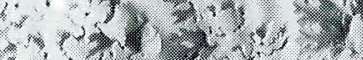
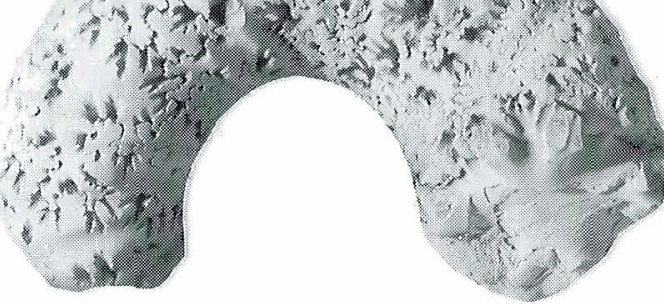

H
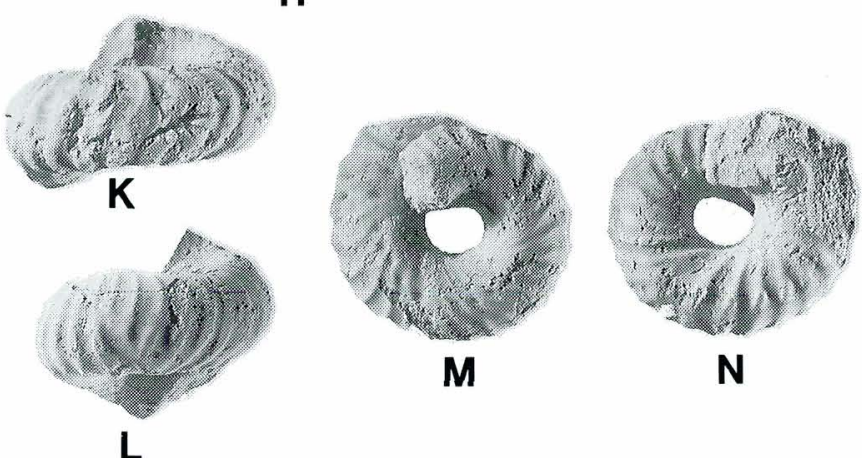

Text-fig. 9. A, B, I-N, Didymoceras tortum (Meek and Hayden, 1858). A, B, USNM 411381. I-K, USNM 411354. L-N, USNM 411358. C-H, Didymoceras cochleatum (Meek and Hayden, 1858). C-E USNM 411368; F-H, USNM 411369. A-H from the Gregory Member of the Pierre Shale, Baculites gregoryensis zone, below Fort Collins on the Missouri River, South Dakota. I-N from the base of the Annona Chalk, Okay Quarry, Howard County, Arkansas. 

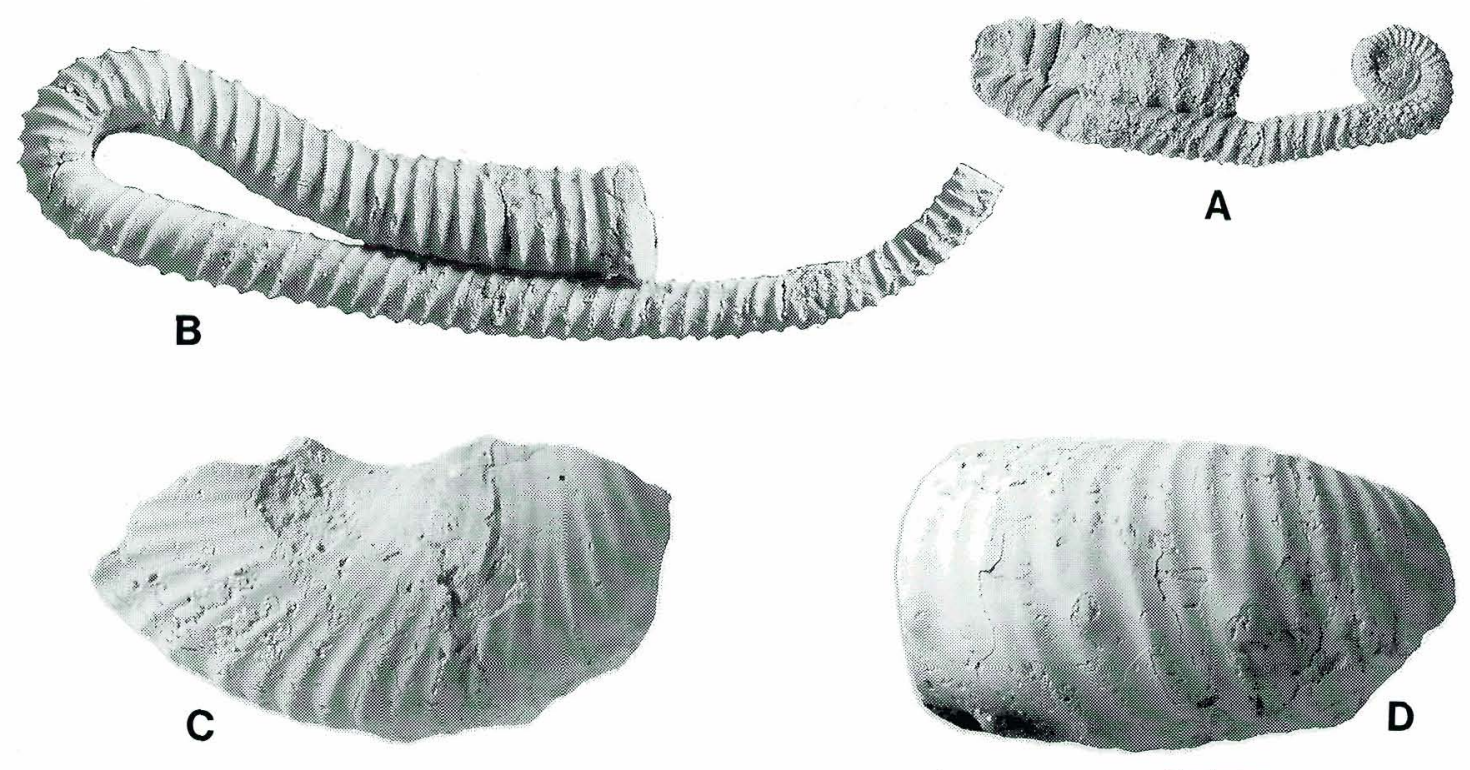

Text-fig. 10. A, Oxybeloceras meekanum (Whitfield, 1877), a microconch, USNM 411291, Pierre Shale, Didymoceras cheyennense zone. Lone Tree Reservoir, Fort Collins, Colorado. B, Oxybeloceras crassum (Whitfield, 1877), a macroconch, private collection of K. Hirsch, Denver, Colorado, Pierre Shale, Baculites scotti zone, Pueblo, Colorado. C, D, Didymoceras cochleatum (Meek and Hayden, 1858), USNM 411370, from the Gregory Member of the Pierre Scale, below Fort Collins on the Missouri Riber. South Dakota. All figures are natural size.

culate ribs between tuberculate groups. The type is lost, but topotype fragments are shown in textfig. $9 \mathrm{C}-\mathrm{H}$.

Occurrence: Upper Campanian, basal phosphate bed of Annona Chalk, Okay Quarry, Okay, Howard County, Arkansas. In the United States Western Interior, $N$. $(N$.) tortum has been found in the middle part of the Pierre Shale and equivalent rocks in South Dakota and Wyoming.

Didymoceras cochleatum (Meek and Hayden, 1858)

Plate 1, figs. 29, 30; Plate 2, figs. 10-15; Plate 4, figs 27-32; text-figs. $6 \mathrm{C}$; $7 \mathrm{C} ; 9 \mathrm{C}-\mathrm{H} ; 10 \mathrm{C}, \mathrm{D}$

1858 Turrilites (Helicoceras) cochleatus Meek and Hayden, p. 55.

1858 Helicoceras tenuicostatum Meek and Hayden, p. 56.

1859 Turrilites (Helicoceras) cochleatus Meek and Hayden, p. 684.

1860 Helicoceras tenuicostatum Meek and Hayden, p. 42.

1864 Helicoceras cochleatum Meek and Hayden; Meek, p. 25.

1876 Heteroceras? cochleatum Meek and Hayden; Meek, p. 478, pl. 22, fig. 2.
1876 Helicoceras mortoni var. tenuicostatum Meek and Hayden; Meek, p. 487, pl. 22, fig. 3 .

1894 Didymoceras cochleatum Meek and Hayden; Hyatt, p. 574.

?non 1898 Heteroceras cochleatum Meek and Hayden; Logan, p. 512, pl. 107, fig. 2.

1921 Didymoceras cochleatum Meek sp.; Spath, p. 253, footnote.

Type: The type specimen is lost (fide Meek, 1876, p. 479), and was from "the Great Bend of the Missouri, below Fort Pierre ... from the lower part of the Fort Pierre Group", that is to say from the Gregory Member of the Pierre Shale, upper Campanian Baculites gregoryensis zone.

Description: We refer to this species phosphatic fragments of a slowly expanding, loosely coiled nostoceratid with a near-circular whorl section. Ribs are delicate and markedly rursiradiate on the upper surface of the whorl, sweeping back and concave on the juncture of upper and lower faces, markedly oblique across the outer whorl face, and strong on the lower whorl face. Most of the ribs are single, and bear two rows of subequal 
tubercles, one at mid-flank, the other low on the outer whorl face. A few nontuberculate ribs are present, and some ribs may loop in pairs between tubercles, and there are other minor irregularities and sparse constrictions. The suture is deeply and intricately incised, with bifid lobes and saddles.

Discussion: Study of a large suite of fragments from the Baculites gregoryensis zone of the Western Interior shows Helicoceras tenuicostatum Meek and Hayden, 1858 (p. 56) to be a fineribbed juvenile of this species. Similar variants occur in the Okay fauna (Pl. 1, figs. 29, 30; textfig. $6 \mathrm{C}$ ). As first revising authors we select the name cochleatum for the species. Our best specimens are large body chamber fragments that match some fragments from the type area (textfig. 10C, D). The strong, regularly bituberculate ribs are much sharper on moulds than those $D i$ dymoceras tortum, described above, and the tubercles are higher up the outer whorl face. Didymoceras mortoni, described below, is very similar, but is more densely ribbed.

Occurrence: Upper Campanian, basal phosphate bed of the Annona Chalk, Okay quarry, Okay, Howard county, Arkansas. In the United States Western Interior, $N$. (N.) cochleatum occurs in the zone of Baculites gregoryensis in the Pierre Shale in central South Dakota.

Didymoceras mortoni (Hall and Meek, 1856)

Plate 3, figs. 1-28, 32-37; Plate 4, figs. 14-16; text-fig. 7D

1856 Hamites mortoni Hall and Meek, p. 396, pl. 4 , fig. 3.

1856 Ancyloceras nicolleti Hall and Meek, p. 397 , pl. 4 , fig. 4.

1859 Turrilites umbilicatus Meek and Hayden, $\mathrm{p}$. 56.

1859 Ancyloceras mortoni Meek and Hayden; Hayden, p. 685.

1859 Turrilites umbilicatus (Meek and Hayden); Hayden, p. 684.

1876 Heteroceras umbilicatum (Meek and Hayden); Meek, p. 482, pl. 22, fig. 5.

1921 Didymoceras umbilicatum Meek; Spath, p. 248.

Type: The holotype, by monotype, is AMNH 9550, the original of Hall and Meek 1856, p. 396, pl. 4, fig. 3, from "near Red Cedar Island, thirtyfive miles below Fort Pierre, in division no. 4 of section", that is to say the Gregory Member of the Pierre Shale, upper Campanian Baculites gregoryensis zone.

Description: We have more than 100 phosphatic fragments of this species. The holotype of $\mathrm{Ha}$ mites mortoni corresponds to the initial stage, and many fragments show this part of the ontogeny. The whorl section is circular in intercostal section, and the whorls slowly expand. All fragments show slight asymmetry of ornament. The ribs, which have an index of 5 , are weak and generally slightly oblique on the dorsum. They are strong, straight and narrow on the flanks, and feebly rursiradiate. Most have small flat-topped ventral tubercles that bore septate spines. A blunt rib, sometimes split into a pair of riblets, links the tubercles across the venter. Occasional ribs may lack other tubercles, and nontuberculate annulate ribs are occasionally developed. In the succeeding tight helicoid stage, the upper surface of the whorls is ornamented by delicate convex ribs. These sweep back across the juncture of the outer and upper whorl faces, then strenthen and follow a sinuous, oblique course across the outer whorl face. One of the tubercles migrates to a mid-lateral position, and pairs of tubercles may link at an oval, flat-topped node that was the base of a septate spine. Other ribs intercalate between the tuberculate groups or simply cross the flank without developing tubercles. A rib or pair of ribs link to a second, transversely elongate tubercle that lies at the juncture of the outer and lower whorl faces, and together with nontuberculate ribs are well-developed and convex on the lower whorl face. Some fragments have small depressions on the upper whorl face that housed the lower tubercle row of the preceding whorl; others have irregularly developed constrictions. USNM 411372 shows the body chamber; it has strong ribs that loop between tubercles and branch and intercalate. Well-developed constrictions, flanked by flared collar-ribs are present. The suture has deeply incised bifid saddles with narrow stems and lobes with narrow splayed elements.

Discussion: The holotype of Hamites mortoni Hall and Meek, 1856 (p. 396, pl. 4, fig. 3) is a 
wholly septate fragment showing a style of ribbing and tuberculation identical to that developed by our specimens. The holotype of Heteroceras umbilicatum Meek and Hayden. 1858 (= 1876 , p. 482 , pl. 22 , fig. 5) USNM 472 , is from the "Great Bend of the Missouri below Fort Pierre, Dakota, from the lower part of the Fort Pierre Group", from rocks now assigned to the Gregory Member of the Pierre Shale. The specimen is a body chamber whorl $80 \mathrm{~mm}$ in diameter. It can be matched in the larger fragments before us.

Occurrence: Upper Campanian, basal phosphate bed of the Annona Chalk, Okay quarry, Okay, Howard County, Arkansas. In the United States Western Interior, D. mortoni is widely distributed in the zones of Baculites gregoryensis $B$. reduncus and $B$. scotti in the middle part of the Pierre Shale and equivalent rocks in South $\mathrm{Da}$ kota, Wyoming, Colorado and New Mexico.

Didymoceras donezianum (Mikhailov, 1951)

Plate 5, figs. 1-4, 6, 9-13; Plate 6, figs. 10-13

1913 Heteroceras polyplocum Roemer var. Schlonbachi Favre sp; Nowak, p. 385, pl. 41, fig. 14; pl. 44, fig. 42.

1951 Bostrychoceras polyplocum Roemer (?) var. doneziana var. nov. Mikhailov, p. 53, pl. 4, figs. 23, 24.

1951 Bostrychoceras polyplocum Roem. var. schloenbachi Favre; Mikhailov, p. 51, pl. 2, figs. 13, 14; pl. 3, figs. 16, 19; pl. 4, figs. 20-22.

?1951 Bostrychoceras polyplocum Roem. var. renngarteni var. nov. Mikhailov, p. 54, pl. 3, figs. 17, 18.

1959 Bostrychoceras schloenbachi (Favre); Naidin and Shimanskij, p. 180, pl. 4, figs. 1-5.

1974 Bostrychoceras schloenbachi (Fabre, 1869); Naidin, p. 166 (pars), pl. 55, figs. 2-8.

1980 Didymoceras donezianum donezianum (Mikhailov, 1951); Blaszkiewicz, p. 24, pl. 5, fig. 1; pl. 7, figs. 9-15, 18.

1986 Nostoceras (Nostoceras) archiacianum (d'Orbigny); Kennedy, p. 90 (pars), non text-figs. $31 \mathrm{~b}-\mathrm{e}, \mathrm{h}$, i.

Type: Holotype by original designation is the original of Mikhailov, 1951, pl. 4, figs. 23, 24, from the upper Campanian of the Donets Basin, USSR.

Description: Fifteen distored composite moulds are referred to this species. There are three growth stages preserved by the present material. An initial open helix, the whorls not in contact, with a high translation rate is followed by a tightly coiled helix, then a recurved body chamber section. The first stage is ornamented by annular ribs that are much narrower than the interspaces, strong and transverse on the dorsum and venter with small ventral tubercles. The first part of the helical stage has simple oblique bituberculate ribs, but this is succeeded by a distinctive pattern of ribs and tubercles that extends onto the uncoiled body chamber. Pairs of narrow ribs extend down from the upper whorl surface, and link to well-developed tubercles; because of crushing, their position on the whorl face cannot be determined with any confidence. Ribbing weakens across the median zone of the outer whorl face between tubercles in most specimens, where only a single broad rib links the tubercles in the two rows. Single strong ribs extend from the lower tubercle row onto the lower whorl face. The specimen preserving the body chamber is crushed, but is appears to have been recurved into a ' $U$ '; the ornament is comparable to that on the last whorl of the spire.

Discussion: Although crushed, the Okay specimens show beyond any doubt that the open helix represented by the type material of Bostrychoceras polyplocum var. doneziana Mikhailov, 1951 (p. 53, pl. 4, figs. 23, 24) is the ontogenetic stage that precedes the upper Campanian helices with ribs on the upper part of the whorl face that link to the upper row of tubercles, described as Bostrychoceras polyplocum var. schloenbachi by Mikhailov (1951, p. 51, pl. 2, figs. 13, 14; pl. 3, figs. 16,19 ; pl. 4 , figs. 20,22 ). Blaszkiewicz (1980, p. 27) noted that these Campanian specimens were not true schloenbachi, a Maastrichtian species reviewed subsequently by Kennedy and Summesberger (1987, p. 30, pl. 2, figs. 1-5). Kennedy (1986, p. 90) wondered if donezianum might be a variant of Nostoceras archiacianum, a species with simple ribbing, but the present material suggests they are distinct enough. The ribbing 

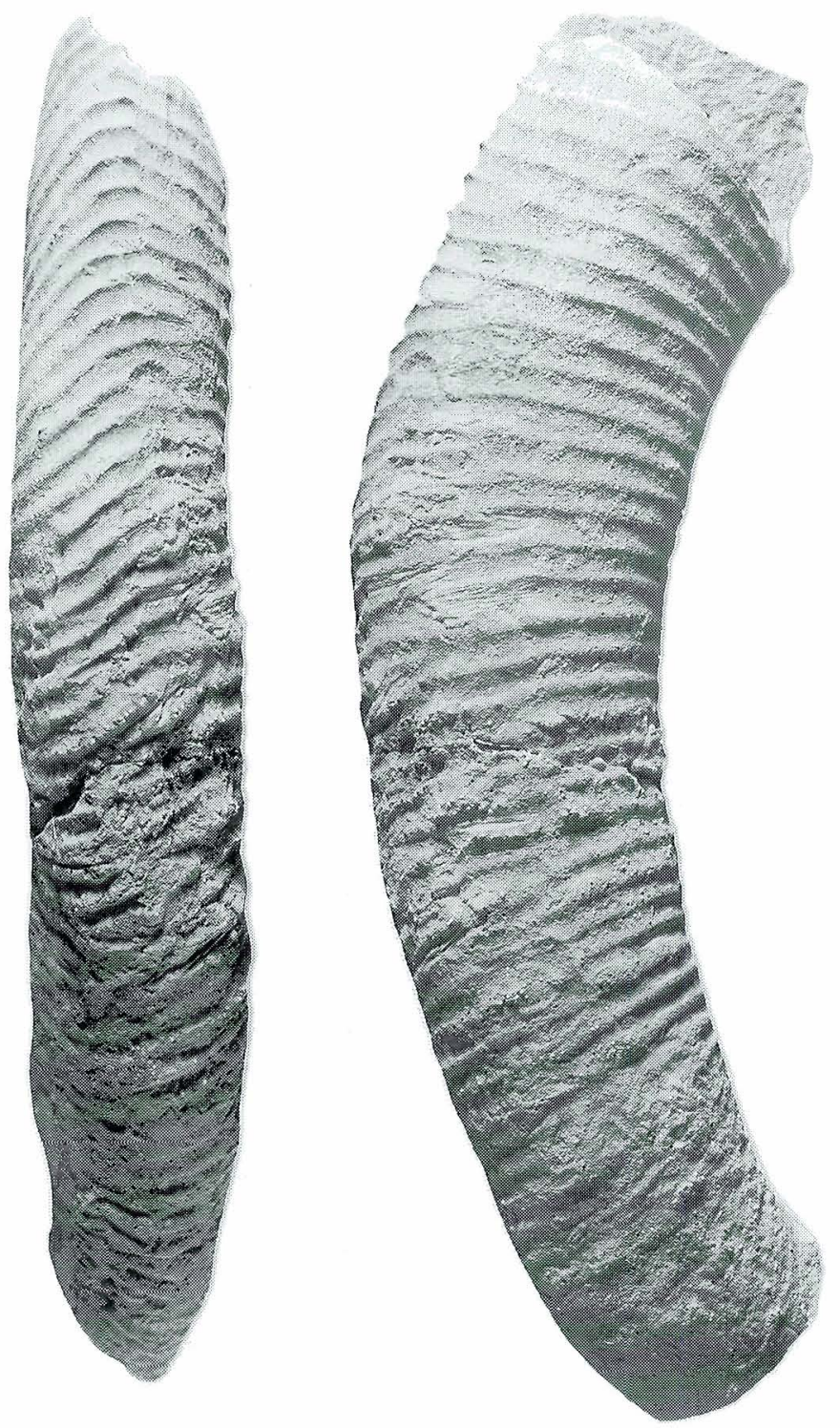

Text-fig. 11. Didymoceras sp. nov., USNM 411347, from the top of the Ozan Formation at the Okay quarry, Okay, Howard County, Arkansas.

pattern of $D$. donezianum is quite distinct from that of any of the other nostoceratids described here.

Occurrence: Upper Campanian, top of Ozan Formation, Okay quarry, Okay, Howard County, Arkansas. Upper Campanian D. donezianum zone in Poland and also known from the Donets Basin in the USSR.

Didymoceras sp.

Plate 4, figs. 25, 26; text-fig. 6A
Description: USNM 411361 is a wholly septate fragment $36 \mathrm{~mm}$ long with a slightly depressed subcircular whorl section and a maximum preserved whorl height of $15.5 \mathrm{~mm}$. The dorsum shows slight distortions and irregularities, which indicate it to be from the juncture of the loosely and tightly helicoid parts of a Didymoceras species. The rib index is 8 . Ribs are weak and feebly convex on the dorsum strengthening over the flanks and passing straight across the venter, where they vary somewhat in strength and direc- 
tion although generally slightly oblique. Some but not all ribs show the faintest trace of flattened expanded areas that we take to be the bases of septate spines. Suture with deeply incised bified lobes and saddles (text-fig. 6A).

Discussion: This fragment represents a further species of Didymoceras, closest to $D$. cochleatum, described above, but with feebler ribbing and near-obsolete tuberculation. The specimen is inadequate for formal description from the available material.

Occurrence: Upper Campanian, basal phosphate bed of Annona Chalk at the Okay Quarry, Okay, Howard County, Arkansas.

Didymoceras sp. nov.

Text-fig 11

Description: A very large fragment of a crushed composite mould $160 \mathrm{~mm}$ long represents an undescribed species of Didymoceras characterised by a very low spire, and high apical angle, corresponding in gross morphology to the spire of Planostoceras of Lewy, 1967. Ribs are strong, sharp, and narrower than the interspaces; the rib index cannot be determined because of the crushing. The ribs are oblique and strong on the dorsum, feebly concave on the upper whorl surface and sweep back on the outer whorl face. Two rows of small tubercles are present, linked by a single rib, and with several nontuberculate ribs between the tuberculate ones.

Discussion: Comparable material occurs in the upper Campanian parts of the Pierre Shale of the Western Interior, and represents a distinct undescribed low helical species. Coiling and size alone distinguish it from all other Didymoceras.

Occurrence: Upper Campanian, top of Ozan Formation, Okay quarry, Okay, Howard County, Arkansas.

Family DIPLOMOCERATIDAE Spath, 1926, p. 81

[= Neocrioceratinae Spath, 1953, p. 17]

Subfamily DIPLOMOCERATINAE Spath, 1926, p. 81

[= Scalaritinae Ward, 1976, p. 455]
Genus Neancyloceras Spath, 1926, p. 80

Type species: Ancyloceras bipunctatum Schlüter, 1872 , p. 98 , pl. 29 , figs. $1-3$, by original designation.

Neancyloceras cf. bipunctatum (Schlüter, 1872)

Plate 6, fig. 17

compare:

1872 Ancyloceras bipunctatum Schlüter, p. 98, pl. 29, figs. 1-3.

1982 Ancyloceras bipunctatum Schlüter, 1872; Klinger, p. 221, figs. 1, 1-3, 2-8A-E, 9 (with full synonymy).

1986 Neancyloceras cf. bipunctatum (Schlüter, 1872a); Kennedy, p. 104, pl. 16, fig. 5.

Type: Lectotype, by subsequent designation by Blaszkiewicz, 1980, p. 29 in the original of Schlüter, 1872, pl. 29, fig. 3, refigured by Klinger, 1982, figs. 3, $4 \mathrm{a}$, from the upper Campanian of Ahlten, Germany.

Description: Part of a crushed criocone $85 \mathrm{~mm}$ across has a rib index of 6-7. The ribs are weak on the dorsum, but strengthen across the flank, where they are straight to feebly convex and markedly prorsiradiate, strong, and narrower than the interspaces. Most bear sharp ventral tubercles. A few ribs weaken markedly on the outer flank, and cross the venter without developing tubercles, while towards the larger and of the specimen one tuberculate rib is markedly strenthened, and is followed by a deepened interspace/incipient constriction.

Discussion: The fragment differs in no significant respects from the lectotype and other criocone growth stages described by Klinger (1982).

Occurrence: Upper Campanian, top of Ozan Formation, Okay quarry, Arkansas. The species also occurs in the upper Campanian of Aquitaine, France, the German Federal Republic and the Vistula Valley, Poland.

Subfamily POLYPTYCHOCERATINAE Matsumoto, 1938, p. 193

[nom. transl. Wiedmann, 1962, p. 185, ex Polyptychoceratidae Matsumoto, 1938.

Genus Oxybeloceras Hyatt, 1900, p. 588 


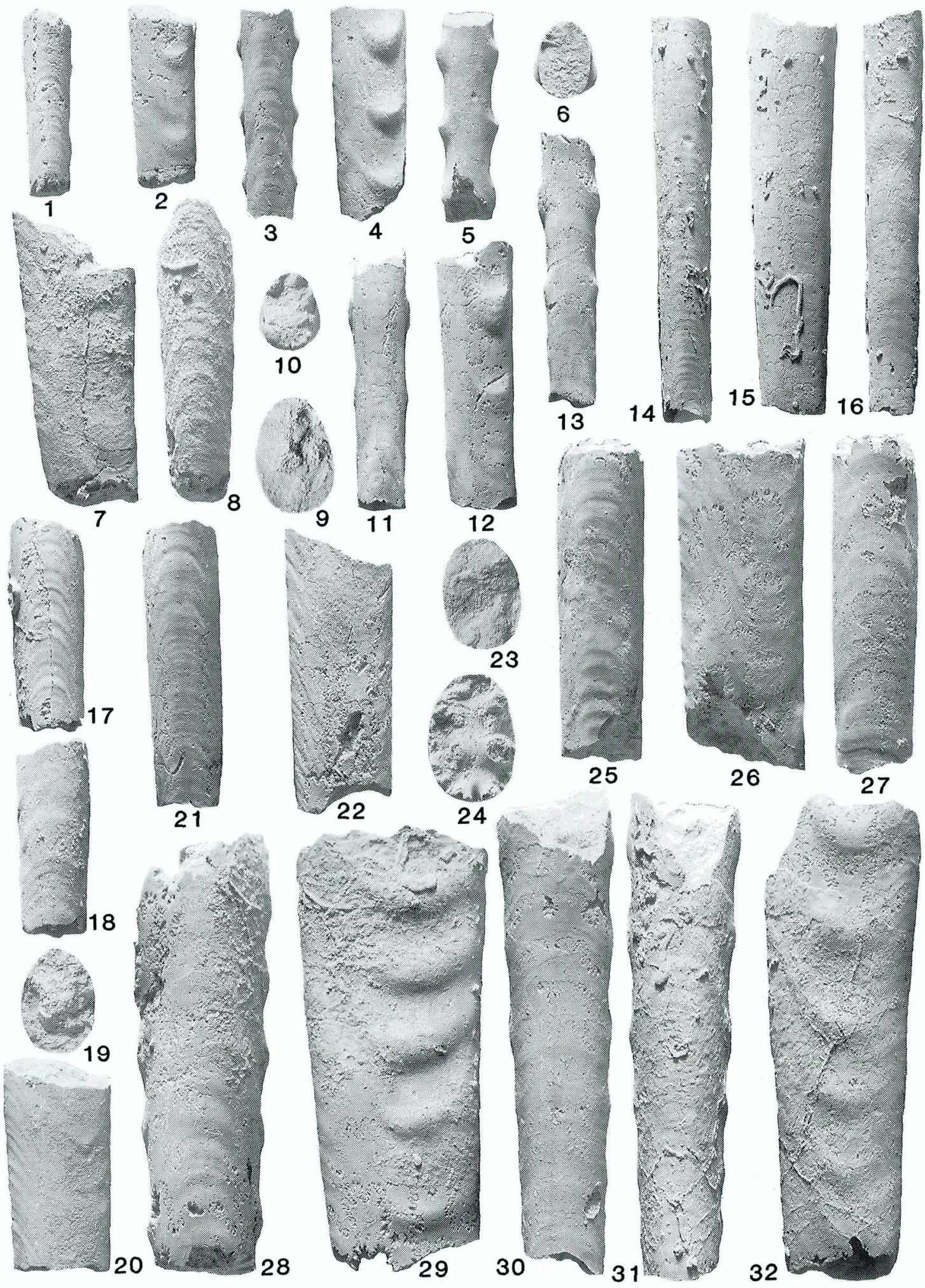

Plate 7. Figs. 1-6, 10-13. Baculites taylorensis Adkins, 1929. 1, 2, USNM 411296; 3-6, USNM 411295; 10-13, USNM 411299. Figs. 7-9, 14-27. Baculites sp. 7-9, USNM 411307; 14-16, USNM 411305; 17-20, USNM 411304; 21-23, USNM 411302; 24-27. USNM 411306. Figs. 28-32. Baculites reduncus Cobban, 1977. 28, 29, USNM 411300; 30-32, USNM 411301. All specimens are from the basal phosphate bed of the Annona Chalk at the Okay quarry, Okay, Howard County, Arkansas. All figures are natural size. 


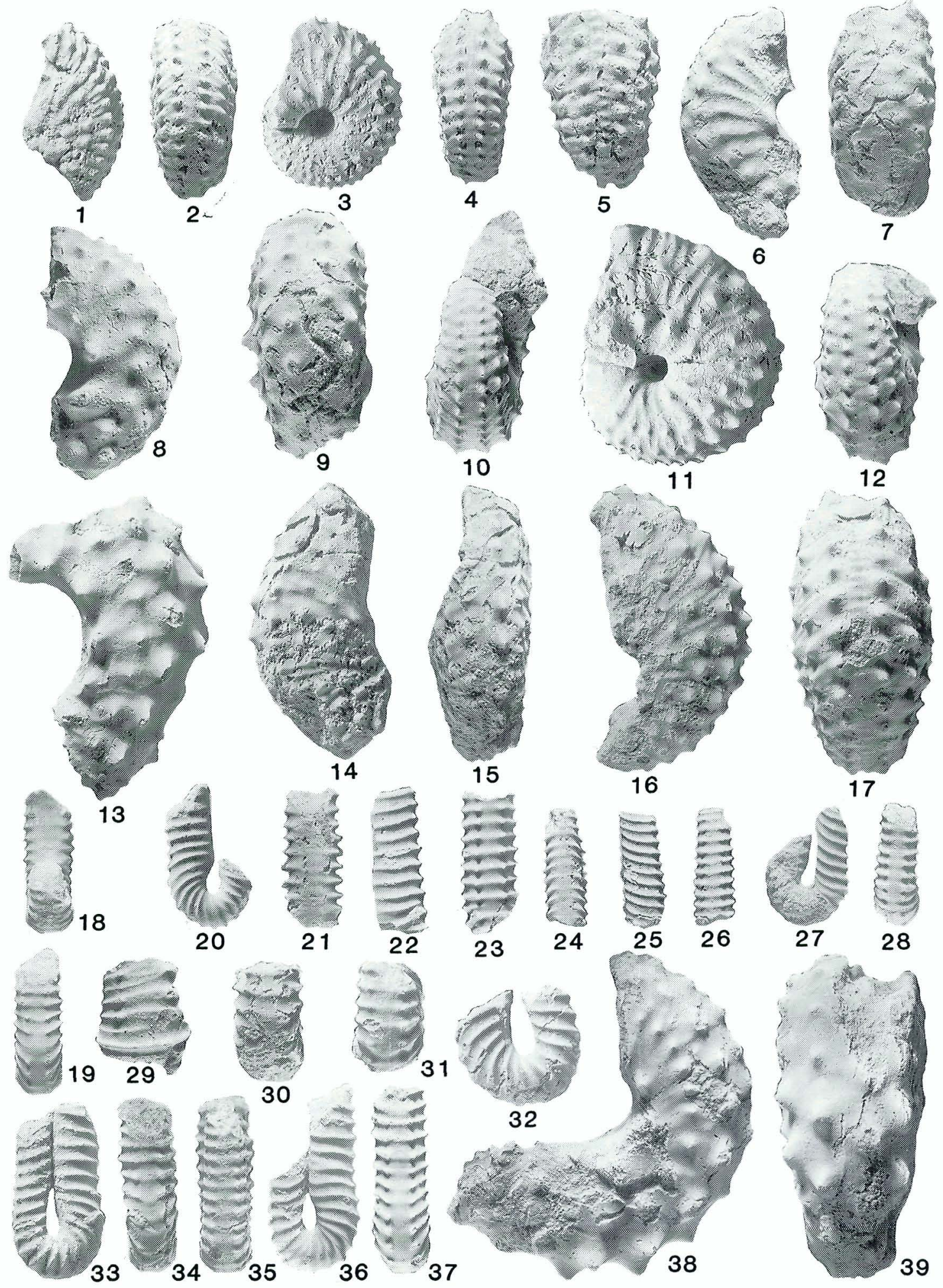

Plate 8. Figs. 1-17, 38, 39. Trachyscaphites redbirdensis Cobban and Scott, 1964. 1, 2, USNM 411273; 3, 4, USNM 411277; 5, USNM 411279 : 6, 7, USNM 411274; 8, 9. USNM 411276; 10-12, USNM 411278; 13, USNM 411280; 14, 15, USNM 411281; 16, 17, USNM $411275 ; 38,39$. USNM 41272. Figs. 18-37. Oxybeloceras crassum (Whitfield, 1877). 18-20, USNM 411286; 21-23, USNM 411288; 24-26, USNM 411289; 27, 28, USNM 411287; 29, USNM 411283; 30-32, USNM 411284; 33-35, USNM 411285; 36, 37. USNM 411290. All specimens are from the basal phosphate bed of the Annona Chalk at the Okay quarry, Okay, Howard County, Arkansas. 
Type species: Ptychoceras crassum Whitfield, 1877 , p. 45 , by orignal designation.

Diagnosis: strongly dimorphic. An initial open planispiral coil is succeeded by a long, initially markedly curved, then near-straight shaft; a narrowly rounded curved section leads to a second shaft coiled in the same plane and initially separated from the first shaft, leaving a tear-shaped opening; shafts in close contact thereafter with dorsum of second shaft impressed to accommodate dorsum of first shaft. Body chamber extends for all of second shaft. Ornament of strong, distant ribs with small ventral tubercles; ribs rursiradiate on spire, aperture preceded by constriction followed by flared rib then a few nontuberculate ribs. Suture with broad-stemmed broad bifid saddles and narrower, moderately incised lobes.

Discussion: Oxybeloceras has been regarded as a synonym of Solenoceras Conrad, 1860, of which Hamites annulifera Morton, 1842 (p. 321, pl. 11, fig. 4) is type species; the type specimen of $H$. annulifera was reillustrated by Reeside (1962, p. 121. pl. 70, figs. 8-10), and the species discussed by Cobban (1974, p. 81). Oxybeloceras and Solenoceras are quite distinct in our view. They differ in that Solenoceras consists of two straight parallel shafts, lacking the initial planispire of $O x$ ybeloceras. It has the shafts closely adpressed for all of their length and constrictions with associated flared ribs occur on body chamber and phragmocone. The ribs bearing tubercles are weaker than in Oxybeloceras, and the tubercles may efface.

Specimens of Oxybeloceras before us are referred to $O$. crassum Whitfield, 1877 , the type species, originally described from the upper Campanian Baculites scottii zone of the northern United States Western Interior. A second species, Osybeloceras meekanum (Whitfield, 1877) (p. $44 ; 1880$, p. 457 , pl. 16 , figs. 1,2 ; see text-fig. $10 \mathrm{~A}$ herein) is from a higher horizon, the Didymoceras cheyennense zone in the Western Interior, and also occurs in the Mount Laurel Sand at the well-known Biggs Farm locality in New Jersey on the Chesapeake and Delaware Canal. $O x$ ybeloceras binodosa Haughton, 1925 (p. 278), is uninterpretable from the description. Haughton wondered if it might be part of a Didymoceras, and Howarth 01965, p. 343) appears to regard it as possibly a fragment of ?Solenoceras.

Occurrence: Upper Campanian of the northern part of the United States Western Interior, Arkansas and Texas. Baculites scotti to Didymoceras cheyennense zones.

Oxybeloceras crassum (Whitfield, 1877)

Plate 8, figs. 18-37; text-figs. 7B; 10B

1877 Ptychoceras crassum Whitfield, p. 45.

1880 Ptychoceras crassum Whitfield, p. 459, pl. 16, figs. 3-5.

1894 Ptychoceras crassum (Whitfield); Hyatt, p. 579, pl. 14, figs. 18-21.

non 1899 Ptychoceras near crassum Whitfield; Harris, p. 297, pl. 51, fig. 5.

1900 Oxybeloceras crassum (Whitfield); Hyatt, p. 588.

1910 Ptychoceras (Oxybeloceras) crassum Whitfield; Grabau and Shimer, p. 20, figs. $1464 \mathrm{~b}, \mathrm{c}$.

1921 Ptychoceras (Oxybeloceras) crassum Whitfield; Grabau, text-fig. 1754i, j.

Type: Holotype, by monotypy, USNM 12324, the original of Whitfield, 1877 , p. 45 , figured by Whitfield, 1880 , pl. 16, figs. 3, 4, 6, and from "limestone of the Fort Pierre group, on Old Woman's Fork, Black Hills". This locality is in the Baculites scotti zone in the Red Bird Silty Member of the Pierre Shale.

Description: We have 56 phosphatised fragments of this species. 25 are parts of the curved portion, with or without associated shafts. They fall into two size classes; 18 (72\%) are small, with a whorl breadth on the curvature of $6.5-8 \mathrm{~mm}$, and 7 $(28 \%)$ are significantly larger, with whorl breadth of $11 \mathrm{~mm}$ on the curvature; this may reflect size dimorphism, but the evidence is inconclusive. The best-preserved fragments show a shell consisting of two parallel shafts joined by a strongly curved portion. The small shaft is straight, but following the curvature the large shaft bows out, leaving a tear-shaped opening between the shafts. Where in contact, the shafts are pressed tight together, and the dorsum of the large shaft may be concave to accommodate the dorsum of the smaller shaft. The whorl section is a depressed oval in intercostal section, with the great- 
est breadth around mid-flank; the venter is flattened to feebly concave in costal section. The whorl section expands slowly on the shafts, but there is a pronounced increase in diameter from the smaller to the larger shaft across the curved section. Ornament consists of even, single ribs; the rib index is $3-4$. On small shafts, the ribs are weak and weakly concave on the dorsum; they strenthen across the dorsolateral area and become sharp, narrow, distant, prorsiradiate and feebly concave on the inner flank and straight on the outer flank. All ribs bear small, sharp, bullate ventral tubercles, linked across the venter by a lower, broader straight transverse rib. Ribs change from prorsiradiate to rursiradiate around the curvature, and are markedly rursiradiate on the larger shaft. The ribs are effaced on the impressed dorsal zone of the larger shaft, and ventral ribbing weakens markedly on the bulge associated with the transient opening between the two shafts. The aperture is preceded by a constriction followed by a flared tuberculate rib and a few nontuberculate ribs. The phragmocone extends to the beginning of the curvature, but never onto the larger shaft. The suture has broad, moderately incised bifid saddles with broad stems, and narrower, asymmetrically bifid saddles.

Discussion: The Ptychoceras near crassum Whitfield of Harris (1899, p. 297, pl. 51, fig. 5) has the limbs closely in contact throughout, and seems rather to be a Solenoceras than Oxybeloceras. $O$. crassum and $O$. meekanum (Whitfield, 1877) (p. 44,1880 , p. 457 , pl. 16 , figs. 1,2 ; see text-fig. 10A) differ chiefly in the character of the body chamber ribbing, which is much more distant, narrower and strongly flared in meekanum. An adult microconch is figured by Hirsch (1975, fig. 10 ; note that the captions of his figs. 10 and 11 are reversed).

Occurrence: Upper Campanian, basal phosphate bed of the Annona Chalk, Okay quarry, Okay, Howard County, Arkansas. In the United States Western Interior, $O$. crassum is found in the zones of Baculites scotti and Didymoceras cheyennense in the Pierre Shale in South Dakota, Woyming and Colorado.

Family BACULITIDAE Gill, 1871, p. 3

[= Eubaculitinae Brunnschweiler, 1966, p. 24]
Genus Baculites Lamarck, 1799, p. 80

[= Homaloceratites Hupsch, 1768, p. 110 (non binomen; Euhomaloceras Spath, 1926, p. 80]

Type species: Baculites vertebralis Lamarck, 1801 , p. 103 , by subsequent designation by Meek, 1876, p. 391.

Baculites taylorensis Adkins, 1929

Plate 6, figs. 1-9; Plate 7, figs. 1-6; 10-13; textfig. $8 \mathrm{~B}, \mathrm{D}$

1929 Baculites taylorensis Adkins, p. 204, pl. 5, figs. 9-11.

non 1970 Baculites cf. taylorensis Adkins; Collignon, p. 13, pl. 612, fig. 2285.

Types: The holotype, by original designation, is the original of Adkins, 1929, pl. 5, figs. 9-11 from a phosphate bed in the "Taylor formation" 12.4 $\mathrm{km},(7.5$ miles) northeast of Austin on the Austin-Manor Road, Travis County, Texas. An uspecified number of prartypes are from the same horizon and locality.

Material: We have several hundred phosphatic fragments; a few unphosphatised composite moulds may also belong here. The shell expands slowly. The whorl section is compressed, ovoid with dorsum broadly rounded, the venter narrower. Strong widely separated crescentic dorsolateral bullae occur at intervals equal to 1 to 1.5 times the whorl height. These bullae are strongest on the dorsal side, but decline abruptly across the dorsolateral shoulder, and efface across the dorsum. They decline on the ventral part of the flank and project strongly forward as a delicate, straight rib or ribs that intersect the venter at $25-30^{\circ}$. The flanks between bullae are nearly smooth on moulds, but some specimens show straight prorsiradiate intercalated dorsolateral ribs. Venters are ornamented by low, convex ribs and striae. Similar, broadly convex but weaker ornament is present on the dorsum. Suture with broad, bifid, little-incised saddles and narrower, bifid lobes.

Discussion: We have compared material referred to this species with abundant topotypes in the USGS collections, all of which are of the strongly noded type described here. $B$. taylorensis is separated from specimens here referred to $B$. re- 
duncus Cobban, 1977 (p. 459, figs. 2-6) by virtue of the presence of distant umbilicolateral nodes rather than the long, dorsolateral to mid-lateral crescentic ribs of reduncus. Juveniles of $B$. taylorensis and $B$. asperiformis are very similar, differing in that asperiformis has crescentic ribs rather than nodes (Cobban, 1962, p. 708, pl. 106, figs. 1-16); the same difference separates taylorensis from B. mclearni Landes, 1940 (see Cobban, 1962 , p. 712 , pl. 165 , fig. 15 ; pl. 107 , figs. 17-19; text-figs. $1 \mathrm{~g}, \mathrm{~h})$. The Baculites cf. taylorensis of Collignon (1970, p. 13, pl. 612, fig. 2285) from the middle Campanian of Madagascar is much closer ribbed than topotypes of the same diameter.

Occurrence: Upper Campanian, basal phosphate bed of Annona Chalk, Okay quarry, Okay Howard County, Arkansas. The species also occurs widely in north Texas.

Baculites reduncus Cobban, 1977

Plate 7, figs. 28-32

1977 Baculites reduncus Cobban, p. 459, figs. 2-6.

Type: Holotype is USNM 108909 from the Rock River Formation of the Mesaverde Group at USGS Mesozoic locality 22935 near Rock River, Wyoming, upper Campanian, B. reduncus zone.

Description: This species is represented by only a few specimens. The expansion rate is quite high, and the shell slightly curved. The whorl section is stoutly ovate with dorsum narrower than venter. The dorsal half of the flanks bear low, broad crescentic ribs, $2-3$ in a distance equal to the whorl height. Ribs decline markedly over the dorsolateral area, and they are largely effaced on the dorsum. The ribs project forward and decline over the ventral part of the flank and leave a nearly smooth venter to moulds. Suture quite deeply incised with a relatively narrow-stemmed $\mathrm{L}$, bifid $\mathrm{L} / \mathrm{U}$, and broad bifid $\mathrm{U}$.

Discussion: Presence of close-spaced crescentic ribs rather than distant nodes distinguishes this species from the co-occurring Baculites taylorensis. Cobban. (1977) discusses differences from other species of the genus.
Occurrence: Upper Companian, basal phosphate bed of Annona Chalk, Okay quarry, Okay, Howard County, Arkansas. In the United States Western Interior the species characterises a zone between that of $B$. gregoryensis and $B$. scotti in Wyoming and Colorado (Cobban 1977).

Baculites sp.

Plate 7, figs. 7-9, 14-27; text-fig. 8C

Description: We have several hundred phosphatised fragments of this species, septate to a whorl height of $28 \mathrm{~mm}$. The angle of taper is low and averages $3^{\circ}$ at a whorl height of $14 \mathrm{~mm}, 2,5^{\circ}$ at a whorl height of $12.5 \mathrm{~mm}$ and $2^{\circ}$ at a whorl height of $22.5 \mathrm{~mm}$. The whorl section is stout with a whorl breadth to height ratio of as much as 0.64 , a broadly rounded dorsum and venter and flattened subparallel flanks. Ornament is very weak. Concave riblets and striae occupy the dorsal half of the flank, and cross the venter in a broad convexity. They project strongly forwards on the outer flank, flex back and are feebly convex on the ventrolateral shoulder, where they strengthen and cross the venter in a narrow linguoid convexity. The venter is strongly ribbed when compared to the dorsum. The suture is characterised by moderate incision and long, narrow bifid lobes $\mathrm{L}$ and $U$ and saddles $E / L$ and $L / U$.

Discussion: The suture alone separates this species from co-occurring $B$. reduncus and B. taylorensis and justifies recognition of a third Baculites species in the fauna, rather than merely regarding this numerically dominant form as a smooth variant of one or other of these species. This is supported by the observation that smooth variants are absent from topotype assemblages of $B$. taylorensis and $B$. reduncus. The whorl section and suture are very similar to that of the older 'Baculites smooth sp.' of Cobban (1962, p. 714, pl. 108 , figs. $1-4$; text-fig. $1 \mathrm{i}, \mathrm{j}$ ), as is the large size of septate fragments.

Occurrence: Upper Campanian, basal phosphate bed of Annona Chalk, Okay quarry, Okay, Howard County, Arkansas.

Superfamily SCAPHITACEAE Gill, 1871, p. 3 Family SCAPHITIDAE Gill, 1871, p. 3 Subfamily SCAPHITINAE Gill, 1871, p. 3 
Genus Trachyscaphites Cobban and Scott, 1964, p. E7

Type species: Trachyscaphites redbirdensis Cobban and Scott, 1964, p. E7, pl. 1, figs. 1-7; textfig. 3 , by original designation.

Trachyscaphites redbirdensis Cobban and Scott, 1964

Plate 8, figs. 1-17, 38, 39; text-fig. 8G

1964 Trachyscaphites redbirdensis Cobban and Scott, p. 7, pl. 1 - figs. 1-7; text-fig. 3 .

Types: Holotype, by original designation, is the original of Cobban and Scott (1964, pl. 1, figs. $3-5,7)$ USNM 132309, from the Red Bird Silty Member of the Pierre Shale at U.S. Geological Survey Mesozoic locality D1900, $3.5 \mathrm{~km}$ northeast of Red Bird in the NW $1 / 4$ sec. 13 T. 38 N., R. 62 W., Niobrara County, Wyoming. Paratypes are USNM 132310-132313, from the Red Bird Silty Member in the same general area as that of the holotype.

Description: We have 27 phosphatic fragments of this species. Phragmocone fragments have whorl breadth to height ratios of 0.93 to 1.1 . The largest has the last suture at $40 \mathrm{~mm}$ diameter. Coiling is very involute with a tiny, deep, conical umbilicus, comprising $13 \%$ of the diameter. The intercostal whorl section is polygonal, with the greatest breadth at the umbilical bullae. There are an estimated 11-12 primary ribs that arise on the umbilical wall and bear sharp, bullate umbilicolateral tubercles. In addition some weaker, nontuberculate ribs extend down to the umbilical shoulder. The bullae give rise to pairs of narrow, straight, prorsiradiate ribs, singly or in pairs. These develop feebly bullate outer lateral tubercles in most cases, which number 16 per whorl in the best-preserved specimen. Some of the secondary ribs lack a tubercle and other ribs may intercalate. In USNM 411278, a transient inner lateral row of weak tubercles occurs on the last half whorl of the phragmocone, to give a total of 5 rows on each side. Pairs of narrow ribs or single ribs arise from the outer lateral tubercles and give rise to stronger, clavate inner ventrolateral tubercles; some additional nontuberculate ribs may intercalate at this level. There are $27-28$ inner ventrolateral tubercles in USNM 411277. From the inner ventrolateral clavi a blunt rib or ribs link to slightly weaker outer ventrolateral clavi which alternate across the siphonal line. Delicate ventral riblets loop or zig-zag between outer ventrolateral clavi, which they exceed in number. In some cases tiny siphonal nodes are developed, exceeding in number the outer ventrolateral clavi. All available body chamber fragments are those of microconchs, with a concave umbilical wall and concave profile to the wall in lateral view. All specimens are corroded to varying degrees but four rows of tubercles are developed. They are generally strong on the shaft and weaker towards the adult aperture. Umbilical tubercles are strong and clavate. They give rise to low, broad ribs, singly or in pairs, that link to much weaker and more numerous outer lateral clavi on the shaft. On the hook, the clavi change from clavate to conical. Low folds - hardly ribs link to coarse clavi on the shaft, and to weak clavi on the hook. The total number is 11 in the bestpreserved specimen. Alternating with these are strong subspinose outer ventrolateral clavi alternating in position with the inner ventrolaterals and with the outer ventrolaterals on the other flank. Low ribs link inner and outer ventrolateral clavi, and zig-zag between outer ventrolaterals over the venter. Towards the aperture, flank ribs regenerate as tubercles decline. None of the fragments preserve the aperture. The suture is deeply incised, with broad $\mathrm{E} / \mathrm{L}$ with deep median incision and narrow, plump folioles, deep bifid $\mathrm{L}$, and very narrow $L / U_{2}$ with $U_{2}$ small.

Discussion: The presence of rows of tubercles that alternate in size on the body chamber combined with the presence of as many as five rows of tubercles on the flank of the phragmocone identify these phosphatic fragments as Trachyscaphites redbirdensis. The holotype of $T$. redbirdensis, from the Pierre Shale of eastern Wyoming, is much larger and stouter than any of the specimens from Arkansas, and it and the three paratypes figured by Cobban and Scott $(1964$, pl. 1) represent macroconchs, whereas the much smaller and more slender specimens from Arkansas are mciroconchs.

Occurrence: Upper Campanian, Pierre Shale, Baculites perplexus and $B$. gregoryensis zones, Wyoming; South Dakota and Colorado; basal 
phosphate bed of Annona Chalk, Okay quarry, Okay, Arkansas.

Acknowledgements. R. E. Burkholder, now retired from the United States Geological Survey, Denver, provided field assistance and took most of the photographs. The Arkansas Geological Commission, Little Rock, provided transportation in the field in 1973 and 1974 and B. F. Clardy of the Commission provided invaluable field assistance. Kennedy acknowledges the support of the Natural Environment Research Council (UK), and the staff of the Geological Collections, University Museum, Oxford, and Department of Earth Sciences, Oxford.

\section{Dansk sammendrag}

Det har længe været et problem at korrelere dele af den nordamerikanske kretassiske lags $\varnothing j l e$ med den tilsvarende europæiske. Fundet af rige øvre campanien ammonit faunaer i Howard County, Arkansas, U.S.A. har her betydning.

I topen af Ozan formationen har man fundet Nostoceras (Nostoceras) archiacianum (d'Orbigny, 1842), Didymoceras donezianum (Mikhailov, 1951), D. sp. og Neancyloceras cf. bipunctatum (Schlüter, 1872). Denne fauna er absolut af nordvest europaisk type og kan korreleres med den øvre del af den klassiske øvre campanien Nostoceras (Bostrychoceras) polyplocum zone, $D$. donezianum zonen (defineret af Blaskiewicz 1980) og den nedre del af Belemnitella langei zonen i skrivekridtet.

Det overliggende fosfat nodule lag $\mathrm{i}$ bunden af Annona kalken har ydet kosmopolitiske former som Pseudophyllites, Des mophyllites, Pachydiscus og Menuites plus 11 hereromorfe arter tilhørende formkredsen kendt fra Gulf Coast og det vestlige indre U.S.A. Faunaen kan korreleres med Baculites gregoryensis og B. reduncus zonerne i det vestlige U.S.A.

To nye arter tilhøtende slægten Nostoceras er beskrevet $i$ afhandlingen.

\section{References}

Adkins, W. S. 1929: Some Upper Cretaceous Taylor ammonites from Texas. Univ. Tex. Bull., 2901, 203-211, pls.

Anderson, F. M. 1958: Upper Cretaceous of the Pacific Coast. Mem. geol. Soc. Am., 71, xi +378 pp., 75 pls.

Basse, E. 1952: Ammonoides. Pp. 522-555; 581-688 In PIVETEAU, J. (ED.), Traité de Paléontologie. 2, Paris, Masson.

Blaszkiewicz, A. 1980: Campanian and Maastrichtian ammonites of the Middle Vistula Valley, poland: a stratigraphicpaleontologic study. Pr. Inst. geol., 92, 1-63, 56 pls.

Bottjer, D. J. 1978: Paleoecology, ichnology, and depositional evironments of Upper Cretaceous chalks (Annona Formation; chalk member of Saratoga Formation), southwestern Arkansas. Ph. D. Dissertation, Indiana University, $423 \mathrm{pp}$.

Bottjer, D. J. 1981: Structure of Upper Cretaceous chalk benthic communities, southwestern Arkansas. Palaeogeogr. Palaeoclimatol. Palaeoecol., 34, 225-256.

Bottjer, D. J. 1985: Trace fossils and palaeoenvironments of two Arkansas Upper Cretaceous discontinuity surface. $J$. Paleont., 59, 282-298.

Bottjer, D. J. 1986: Campanian-Maastrichtian chalks of southwestern Arkansas: petrology, paleoenvironments, and comparison' with other North American and European chalks. Cret. Ret., 7, 161-196.

Brunnschweiler, R. O. 1966: Upper Cretaceous ammonites from the Carnavon Basin of Western Australia. 1. The heteromorph Lytoceratina. Bull. Bur. Miner. Resour. Geol. Geophys., Aust., 58, 58 pp., 8 pls.

Casey, R. 1960-1966: A monograph of the Ammonoidea of the Lower Greensand. Monogr. palaeontogr. Soc., i-xxxvi, $1-44$, pls. 1-10 (1960); 45-118, pls. 11-25 (1961); 119-216, pls. 26-35 (1961); 217-288, pls. 36-42 (1962); 289-398, pls. 43-66 (1964); 399-546, pls. 67-91 (1965); 547-582, pls. 91-97 (1966).

Chiplonkar, G. W. and Ghare, M. A. 1976: Palaeontology of the Bagh Beds - Part VII: Ammonoidea. Bull. Earth. Sci., (for 1976), 4 and 5, 1-10, 2 pls.

Christensen, W. K. 1975: Upper Cretaceous belemnites from the Kristiansand area in Scania. Fossils and Strata, 7, 69 pp., 12 pls.

Cobban, W. A. 1962; Baculites from the lower part of the Pierre Shale and equivalent rocks in the Western Interior. J. Paleont., 36, 704-718, pls. 105-108.

Cobban, W. A. 1974: Some ammonoids from the Ripley Formation of Mississippi, Alabama and Georgia. U. S. Geol. Surv. J. Res, , 2, 81-88.

Cobban, W. A. 1977: A new curved baculite from the Upper Cretaceous of Wyoming. U. S. Geol. Surv. J. Res., 5, $457-462$.

Cobban, W. A. and Scott, G. R. 1964: Multinodose scaphitid cephalopods from the lower part of the Pierre Shale and equivalent rocks in the conterminous United States. Prof. Pap. U. S. geol. Surv., 483-E, E1-E13, pls. 1-4.

Collignon, M. 1931: Faunes Sénoniennes du Nord et de rOuest de Madagascar. Annals. géol. Serv. Mines Madagascar, 1, $7-64$, pls. $1-9$.

Collignon, M. 1938: Ammonites Campaniennes et Maastrichtiens de l'ouest et du sud de Madagascar. Annls. géol. Serv. Mines Madagascar, 9, 55-118 (1-65), pls. 1-9.

Collignon, M. 1970: Atlas des fossiles caractéristiques de Madagascar (Ammonites) XVI (Campanien moyen: Campanien supérieur). iv +82 , pls. 607-639, Service géologique, Tananarive.

Conrad, T. A. 1860: Descriptions of new species of the Cretaceous and Eocene fossils of Mississippi and Alabama. $J$. Acad. Nat. Philadelphia, (2), 4, 275-298, pls. 46, 47.

Conrad, T. A. 1868: Appendix A. Synopsis of the invertebrate fossils of the Cretaceous Formation of New Jersey. Pp. 721-731 In Cook, G. H., Geology of New Jersey. Rep. geol. Surv. New Jersey.

Dane, C. H. 1929: Upper Cretaceous formations of southwestern Arkansas. Bull. Ark. geol. Surv., 1, 215 pp., 29 pls.

Dekay, J. E. 1828: Report on several fossil multilocular shells from the state of Delaware: with observations on a second specimen of the new fossil genus EURYPTERUS. Ann. Lyceum nat. Hist., 2, 273-279, pl. 5, figs. 2-5 only.

Douville, H. 1890: Sur la classification des Cératites de la Craie. Bull. Soc. géol. Fr., (3), 18, 275-292.

Elias, M. K. 1933: Cephalopods of the Pierre formation of Wallas County, Kansas and adjacent area. Kans. Univ. Sci. Bull., 21, 289-363, pls. 28-42.

Ernst, G. and Schmid, F. 1979: Multistratigraphische undersuchungen in der Oberkreide des Raumes Braunschweig Hannover. Aspekte der Kreide Europas, IUGS Series A6, 11-46.

Forbes, E. 1846: Report on the Fossil Invertebrata from southern India, collected by Mr. Kaye and Mr. Cunliffe. Trans. geol. Soc. Lond., (2), 7, 97-174, pls. 7-19.

Fritsch, A. and Kafka, J. 1887: Die Crustaceen der böhmischen Kreideformationen. Selbstverlag, Prague, 53 pp.

Fürsich, F. T., Kennedy, W. J, and Palmer, T. J. 1981: Trace fossils at a regional discontinuity surface: the Austin-Taylor (Upper Cretaceous) contact in central Texas. J. Paleont., $55,537-551,4$ pls. 
Gill, T. 1871: Arrangement of the Families of Mollusks. Smithson. misc. Collns., 227 , xvi $+49 \mathrm{pp}$.

Grabau, A. W. 1921: A Textbook of Geology. Part 2. D. C. Heath and Company, New York, 976 pp.

Grabau, A. W. and Shimer, H. W. 1910: North American Index Fossils: Invertebrates, 2, New York, A. G. Seiler and Co., $x v+909$ pp.

Grossouvre, A. de 1894: Recherches sur la craie supéricure, 2, Paléontologie. Les ammonites de la craie supérieure. Mém. Sérv. Carte géol. dét. Fr., 264 pp., 39 pls. (misdated 1893).

Hall. J. and Meek, F. B. 1856: Descriptions of new species of fossils from the Cretaceous formations of Nebraska, with observations upon Baculites ovatus and B. compressus, and the progressive development of the septa in Baculites, Ammonites and Scaphites. Mem. Am. Acad. Arts Sci., new ser., 5, 379-411, pls. $1-8$.

Harris, G. D. 1899: The Cretaceous and lower Eocene fauna of Louisiana, Special Report no. 6 of A preliminary report on the geology of Louisiana. Louisiana Geological Survey, Report for 1899, 289-310, pls. 49-55.

Hauer, F. Von 1858: Uber die Cephalopoden aus den Gosauschichten. Beitr. Palaont. Oest., 1, 7-14, pls. 2-4.

Haughton, S. H. 1925: Notes on some Cretaceous fossils from Angola (Cephalopoda and Echinoidea). Ann. S. Afr. Mus., 22, 263-288, pls. 12-15.

Hayden, F. V. 1859: Catalogue of the collections in geology and natural history obtained by the expedition under command of Licut. G. K. Warren, In Warren, G. K. Preliminary account of exploration in Nebraska and Dakota in the Years 1855-56-57. US War Department Annual Report 1858 (US 35th Congress, Second Session, House Executive Document 2), 673-705.

Henderson, R. A. and McNamara, K. A. 1985: Maastrichtian non-heteromorph ammonites from the Mira Formation, Western Australia. Palaeontology, 28, 35-88, pls. 1-9.

Hill, R. T. 1888: The Neozoic geology of southwestern Arkansas. Arkansas Geological Survey Annual Report for 1888, $2,1-260$.

Hill, R. T. 1901: Geology and geography of the Black and Grand Prairies, Texas. Rep. U. S. geol. Surv., 21, 666 pp.

Hirsch, K. F, 1975: Die Ammoniten des Pierre Meeres (Oberkreide) in den westlichen USA. Der Aufschluss. Jahrgang 26, no. 3, 102-113, 11 figs.

Howarth, M. K. 1965: Cretaceous ammonites and nautiloids from Angola. Bull. Br. Mus. nat. Hist. (Geol.), 10, 335412,13 pls.

Hupsch, J. W. C. A. F. 1768: Neue in der Naturgeschichte des Niederdeutschlands gemachte Entdeckungen einiger selten und Wenig bekanten versteinerten schalthiere. Frankfurt and Leipzig, der Metternischisschen Buchhandlung, 159 pp., 9 pls.

Hyatt, A. 1889: Genesis of the Arietidae. Smithson, Contrib. to Knowl., 673, xi +239 pp., 14 pls.

Hyatt, A. 1894: Phylogeny of an Acquired Characteristic. Proc. Am. Phil. Soc., 32, 349-647, pls. 1-14.

Hyatt, A. 1900: Cephalopoda, pp. 502-604 in Zittel, K. A. von 1896-1900, Texibook of Palaeontology, transl. Eastman, C. R. Macmillan, London and New York.

Hyatt, A. 1903. Pseudoceratites of the Cretaceous. Monogr. U. S. geol. Surv., 44, 351 pp., 47 pls.

Kennedy, W. J. 1986: Campanian and Maastrichtian ammonites from northern Aquitaine, France. Spec. Pap. Palaeont., 36,145 pp., 23 pls.

Kennedy, W. J. and Klinger, H. C. 1977: Cretaceous faunas from Zululand and Natal, South Africa. The ammonite family Tetragonitidae Hyatt, 1900. Ann. S. Afr. Mus., 73, (7), 149-197, 27 figs.

Kennedy, W. J. and Summesberger, H. 1984: Upper Campanian ammonites from the Gschliefgraben (Ultrahelvetic,
Upper Austria). Beitr. Paläont. Öst., 11, 149-206, pls. $1-14$.

Kennedy, W. J. 1987: Lower Maastrichtian ammonites from Nagoryany (Ukrainian SSR). Beitr. Paläont. Öst., 13, 25-78, 16 pls.

Kennedy, W. J. and Wright, C. W. 1983: Ammonites polyopsis Dujardin, 1837 and the Cretaceous ammonite family Placenticeratidae Hyatt. 1900. Palaeontology, 26, 855-873, pls. 85-87.

Klinger, H. C. 1982: Revision of Ancyloceras bipuncratum Schlüter, 1872 (Cephalopoda, Ammonoidea) and discussion of the validity, phylogeny and limits of the genus Neancyloceras Spath, 1926. Ann. S. Afr. Mus.,90, 219239.

Kossmat, F. 1895-1898: Untersuchungen über die Sudindische Kreideformation. Beitr. Paläont. Öst.-Ung., 9, (1895): 97203 (1-107), pls. 15-25 (1-11); 11, (1897): 1-46 (108-153). pls. $1-8(12-19) ; 11,(1898): 89-152$ (154-217), pls. 14-19 (20-25).

Kullman, J. and Wiedmann, J. 1970: Significance of sutures in phylogeny of Ammonoidea. Paleont. Contr. Univ. Kans., 44, 1-32.

Lamarck, J. P. B. A. de M. de 1799: Prodrome d'une nouvelle classification des coquilles. Mém. Soc. Hist. nat. Paris, (1799), 63-90.

Lamarck, J. P. B. A. de M. de 1801: Système des Animaux sans vertebrès. The author; Deterville, Paris, vii $+432 \mathrm{pp}$.

Landes, R. W. 1940: Paleontology of the marine formations of the Montana group, Pt. 2 of Geology of the southern Alberta plains. Mem. geol. Surv. Canada, 221. 129-217, 8 pls.

Lewy, Z., 1967: Some late Campanian nostoceratid ammonites from southern Israel. Israel J. Eath Sci., 16, 165-173.

Logan, W. N. 1898: The invertebrates of the Benton, Niobrara and Fort Pierre Groups. University Geological Survey of Kansas, 4, (Paleontology) (Upper Cretaceous 8), 431-518, pls. $8 \dot{6}-120$.

Matsumoto, T. 1938: A biostratigraphic study on the Cretaceous deposits of the Naibuchi Valley, South Karahuto. Proc. Imp. Acad., 14, 190-194.

Matsumoto, T. 1955: The bituberculate pachydiscids from Hokkaido and Saghalien. Mem. Fac. Sci., Kyushu Univ., Series D. Geology, 5, 153-184, pls. 31-37.

Matsumoto, T. and Obata, I. 1955: Some Upper Cretacous Desmoceratids from Hokkaido and Saghalien. Mem. Fac. Sci., Kyushu Univ., Series D, Geology, 5, 119-151, pls. 24-30.

Meek, F. B. 1864: Check list of the invertebrate fossils of North America; Cretaceous and Jurassic. Smithson. Misc. Collns., 177, 40 pp.

Meek, F, B. 1876: A report on the invertebrate Cretaceous and Tertiary fossils of the upper Missouri county. In Hayden, F. V. Report of the United States Geological Survey of the Territories, 9, lxiv + 629 pp., 45 pls.

Meek, F. B. and Hayden, F. V. 1856: Descriptions of new species of Gasteropoda and Cephalopoda from the Cretaceous formation of Nebraska Territory. Proc. Acad. nat. Sci. Philad., 8, (for 1856), 70-72.

Meek, F. B. 1858: Descriptions of new organic remains collected in Nebraska Territory ... together with some remarks on the geology of the Black Hills and portions of the surrounding county. Proc. Acad. nat. Sci. Philad., 1858: 41-59.

Meek, F. B. 1859: Description of new organic remains collected in Nebraska Territory in the year 1857 by Dr. F. V. Hayden. Proc. Acad. nat. Sci. Philad, 10, 41-59.

Meek, F. B. 1860: Systematic catalogue, with synonyma, etc., of Jurassic, Cretaceous, and Tertiary fossils collected in Nebraska, by the exploring expeditions under the com- 
mand of Lieut. G. K. Warren, of the US Topographical Engineers. Proc. Acad. Nat. Sci. Philad., 1860, 417-432.

Mikhailov, N. P. 1951: [Upper Cretaceous ammonites from the southern part of European Russia and their importance for zonal stratigraphy (Campanian, Maastrichtian)]. Trudy Inst. geol. Akad. Nauk SSSR, 129, (Geology Series 50), 143 pp., 19 pls. [In Russian].

Morton, S. G. 1834: Synopsis of the organic remains of the Cretaceous groups of the United States. Illustrated by nineteen plates, to which is added an appendix containing a tabular view of the Tertiary fossils discovered in America. Key and Biddle, Philadelphia, 88 pp., 18 pls.

Morton, S. G. 1842: Description of some new species of organic remains of the Cretaceous Group of the United States; with a tabular view of the fossils hitherto discovered in this formation. J. Acad. Nat. Sci. Philad., 8, 207-227.

Naidin, D. P. 1974: [Ammonoidea.] Pp. 158-195, pls. 53-70 in Krymgolts, G. Ja. (Ed.). [Atlas of Upper Cretaceous Fauna of Donbass.] "NEDRA", Moscow. [In Russian].

Naidin, D. P. and Shimanskij, V. N, 1959: [Cephalopoda]. In Moskvina, M. M. (Ed). [Atlas of the Upper Cretaceous fauna of the northern Caucasus and Crimeal. 166-220, 23 pls. Moscow. [In Russian].

Nowak, J. 1913: Untersuchungen über die cephalopoden der oberen Kreide in Polen. III Teil. Bull. int. Acad. Sci. Lett. Cracovie. Cl. Sci. math. nat., B, for 1913, 335-415, pls. $40-45$.

Orbigny, A. D'. 1840-1842: Paléontologie francaise: Terrains crétacés. 1. Céphalopodes. Masson, Paris, 1-120 (1840); 121-430 (1841); 431-662 (1842), $148+3$ pls.

Pessagno, E. 1969: Upper Cretaceous stratigraphy of the Western Gulf Coast area, Mexico, Texas and Arkansas. Mem. geol. Soc. Am., 111, xiii +139 pls.

Reeside, J. B. 1962: The Cretaceous ammonites of New Jersey. Bull. New. Jers. Bur. geol. Topogr., 61, 113-137, pls. 68-75.

Roemer, A. 1840-1841: Die Versteinerungen des norddeutschen Kreidegebirges. Hahn'schen Hofbruchhandlung, Hannover, 145 pp., 48 pls. (1-48, pls. 1-7, 1840; 49-145, pls. $8-16,1841)$.

Schlüter, C. 1867: Beitrag zur Kenntniss der jüngsten Ammoneen Norddeutschlands. A Henry, Bonn, 36 pp., 6 pls.

Schlüter, C. 1871-1876: Cephalopoden der oberen deutschen Kreide. Palaeontographica, 21, 1-24, pls. 1-8 (1871); 21, 25-120, pls. 9-35 (1872); 24, 1-144 (121-264) + x, pls. $36-55$ (1876).

Seunes, J. 1891: Contribution a l'étude des Céphalopodes du Crétacé Supérieur de France. I. Ammonites du Calcaire à Baculites du Contentin (Suite). II. Ammonites du Campanien de la région sous-pyrénéenne. Départment de Landes. Mém. Soc. géol. Fr. Paléont., 2, Mémoire 2, 8-22, pls. 12-15 (3-6).

Sharpe, D. 1853-57: Description of the fossil remains of Mollusca found in the Chalk of England. I, Cephalopoda. Monogr. palaeontogr. Soc., 68 pp., 27 pls. $1-26$, pls. $1-10$ (1853); 27-36, pls. 11-16 (1855); 37-68, pls. 17-27 (1857).

Spath, L. F. 1921: On Cretaceous Cephalopoda from Zululand. Ann. S. Afr. Mus., 12, 217-321, pls. 19-26.

Spath, L. F. 1922a: On Cretaceous Ammonoidea from Angola, collected by Profesor J. W. Gregory, D. Sc. F. R. S Trans. R. Soc. Edinb., 53, 91-160, pls. 1-4.

Spath, L. F. 1922b: On the Senonian ammonite fauna of Pondoland. Trans. R. Soc. S. Afr., 10, 113-147, pls. 5-9.

Spath, L. F. 1923: A. monograph of the Ammonoidea of the Gault. Part. 1 Monogr. palaeontogr. Soc., pp. 1-72, pls. $1-4$.

Spath, L. F. 1926: On new ammonites from the English Chalk. Geol. Mag., 63, 77-83, table.

Spath, L. F. 1929: Corrections of cephalopod nomenclature. Naturalist, 871, 269-271.

Spath, L. F. 1953: The Upper Cretaceous Cephalopod fauna of Grahamland. Sci. Rep. Br. Antarct. Surv., 3, 1-60, pls. 1-13.

Stephenson, L. W. 1941: The larger invertebrates of the Navarro Group of Texas (exclusive of corals and crustaceans and exclusive of the fauna of the Escondido Formation). Univ. Tex. Bull., 4101, 641 pp., 95 pls.

Veatch, A. C. 1906: Geology and underground water resources of northern Louisiana and southern Arkansas. Prof. Pap. U. S. geol. Surv., 46, $422 \mathrm{p}$.

Ward, P. D. 1976: Upper Cretaceous Ammonites (SantonianCampanian) from Orcas Island, Washington, J. Paleont., $50,454-461$, pl. 1 .

Wedekind, R. 1916: Uber Lobus, Sutrallobus und Inzision. Zentbl. Miner. Geol. Paläont., for 1916, 185-195.

Whitfield, R. P. 1877: Pteliminary report on the paleontology of the Black Hills, containing descriptions of new species of fossils from the Potsdam, Jurassic, and Cretaceous formations of the Black Hills of Dakota. United States Geographical and Geological Survey of the Rocky Mountain Region, 49 pp.

Whitfield, R. P. 1880: Paleontology of the Black Hills of Dakota. Pp. 325-468, 16 pls. In Newton, H. and Jeney, W. P. Report on the geology and resources of the Black Hills of Dakota. United States Geographic and Geological Survey of the Rocky Mountain Region.

Wiedmann, J. 1962: Ammoniten aus der Vascogotischen Kreide (Nordspanien). 1, Phylloceratina, Lytoceratina. Palaeontographica, 118A, 119-237, pls. 8-14.

Wiedmann, J. 1966: Stammesgeschichte und system den posttriadischen ammonoideen; ein überblick. Neues $\mathrm{Jb}$. Geol. Paläont. Abh., 125, 49-79, pls. 1-2; 127, 13-81, pls. 3-6.

Wright, C. W. 1952: A classification of the Cretaceous Ammonites. J. Paleont., 26, 2 3-222.

Wright, C. W. and Wright, E. V. 1951: A survey of the fossil Cephalopoda of the Chalk of Great Britain. Monogr. Palaeontogr. Soc., 1-40.

Yabe, H. and Shimizu, S. 1926: A study of the genus "Parapachydiscus" Hyatt. Proc. Imp. Acad., 2, 171-173.

Young, K. 1963: Upper Cretaceous ammonites from the Gulf Coast of the United States. Univ. Tex. Bull, 6304, ix +373 pp., 82 pls.

Zittel, K. A. Von 1884: Handbuch der Palaeontology. 1, Abt. 2; Lief 3, Cephalopoda, pp. 329-522. R. Oldenbourg, Munich \& Leipzig.

Zittcl, K. A. Von 1895: Grundzüge der Palaeontologie (Palaeozoologie). R. Oldenbourg, Munich \& Leipzig, vii +972 pp. 